\title{
Understanding the anthropogenic influence on formation of biogenic secondary organic aerosols in Denmark via analysis of organosulfates and related oxidation products
}

\author{
Q. T. Nguyen ${ }^{1,2}$, M. K. Christensen ${ }^{1}$, F. Cozzi ${ }^{1,{ }^{*}}$, A. Zare ${ }^{1,2,3}$, A. M. K. Hansen ${ }^{1}$, K. Kristensen ${ }^{1}$, T. E. Tulinius ${ }^{1}$, \\ H. H. Madsen ${ }^{1}$, J. H. Christensen ${ }^{2}$, J. Brandt ${ }^{2}$, A. Massling ${ }^{2}$, J. K. Nøjgaard ${ }^{2}$, and M. Glasius ${ }^{1}$ \\ ${ }^{1}$ Department of Chemistry and iNANO, Aarhus University, 8000 Aarhus, Denmark \\ ${ }^{2}$ Department of Environmental Science, Aarhus University, 4000 Roskilde, Denmark \\ ${ }^{3}$ Institute of Geophysics, University of Tehran, Tehran, Iran \\ *Department of Plant and Environmental Sciences, University of Copenhagen, 1871 Frederiksberg C, Denmark
}

Correspondence to: Q. T. Nguyen (quynh@chem.au.dk)

Received: 20 December 2013 - Published in Atmos. Chem. Phys. Discuss.: 27 January 2014

Revised: 11 July 2014 - Accepted: 15 July 2014 - Published: 1 September 2014

\begin{abstract}
Anthropogenic emissions of sulfur dioxide $\left(\mathrm{SO}_{2}\right)$ and nitrogen oxides $\left(\mathrm{NO}_{\mathrm{x}}\right)$ may affect concentration levels and composition of biogenic secondary organic aerosols (BSOA) through photochemical reactions with biogenic organic precursors to form organosulfates and nitrooxy organosulfates. We investigated this influence in a field study from 19 May to 22 June, 2011 at two sampling sites in Denmark. Within the study, we identified a substantial number of organic acids, organosulfates and nitrooxy organosulfates in the ambient urban curbside and semi-rural background air. A high degree of correlation in concentrations was found among a group of specific organic acids, organosulfates and nitrooxy organosulfates, which may originate from various precursors, suggesting a common mechanism or factor affecting their concentration levels at the sites. It was proposed that the formation of those species most likely occurred on a larger spatial scale, with the compounds being long-range transported to the sites on the days with the highest concentrations. The origin of the long-range transported aerosols was investigated using the Hybrid Single Particle Lagrangian Integrated Trajectory (HYSPLIT) model in addition to modeled emissions of related precursors, including isoprene and monoterpenes using the global Model of Emissions of Gases and Aerosols from Nature (MEGAN) and $\mathrm{SO}_{2}$ emissions using the European Monitoring and Evaluation Program (EMEP) database. The local impacts were also studied by examining the correlation between selected
\end{abstract}

species, which showed significantly enhanced concentrations at the urban curbside site and the local concentrations of various gases, including $\mathrm{SO}_{2}$, ozone $\left(\mathrm{O}_{3}\right), \mathrm{NO}_{\mathrm{x}}$, aerosol acidity and other meteorological conditions. This investigation showed that an inter-play of the local parameters such as the aerosol acidity, $\mathrm{NO}_{\mathrm{x}}, \mathrm{SO}_{2}$, relative humidity ( $\left.\mathrm{RH}\right)$, temperature and global radiation seemed to affect the concentration level of those species, suggesting the influence of aqueous aerosol chemistry. The local impacts, however, seemed minor compared to the regional impacts. The total concentrations of organosulfates and nitrooxy organosulfates, on average, contributed to approximately $0.5-0.8 \%$ of $\mathrm{PM}_{1}$ mass at the two sampling sites.

\section{Introduction}

Volatile organic compounds (VOC) are emitted from both biogenic and anthropogenic sources and are oxidized to form lower-volatility products partitioning between the gas and particle phase, leading to the formation of secondary organic aerosols (SOA) (Donahue et al., 2006; Kroll and Seinfeld, 2008; Jimenez et al., 2009; Hallquist et al., 2009). In general, the production of biogenic SOA (BSOA) is estimated to be significantly larger than anthropogenic SOA (ASOA) (Goldstein and Galbally, 2007; Heald et al., 2010; Spracklen et al., 2011). For example, Hallquist et al. (2009) 
estimated a many-fold higher annual global production of BSOA ( $88 \mathrm{TgC})$ compared to ASOA (10 TgC), which were, however, associated with high uncertainties. Other studies suggested that ASOA might have been underestimated (De Gouw and Jimenez, 2009), while some local and regional studies have indicated that ASOA could be more substantial than BSOA (Aiken et al., 2009; Fushimi et al., 2011). It is also thought that a substantial proportion of aerosols is formed through condensation of low-volatility biogenic VOC onto existing particles of anthropogenic origin (Carlton et al., 2010), thereby blurring the division between biogenic and anthropogenic SOA. Several studies have indicated that anthropogenic activities could enhance the production of BSOA via different mechanisms, for example by enhancing the incorporation of biogenic VOC products into the condensed phase due to pre-existing organic aerosol from anthropogenic activities, thereby affecting the SOA yield by the complex effect of the anthropogenic species $\mathrm{NO}_{\mathrm{x}}$ and nitrate $\left(\mathrm{NO}_{3}\right)$ radical (a nighttime product of $\mathrm{NO}_{2}$ and ozone) or affecting new particle formation and growth where sulfuric acid has been identified as having an essential role in new particle formation (Aiken et al., 2009; Carlton et al., 2010; Szidat et al., 2006, 2009; Hoyle et al., 2011; Kulmala et al., 2004a). Further research is thus required on the actual impact of anthropogenic emissions on the formation and growth of SOA formed from biogenic VOC.

Several classes of VOC precursors, which are either reactive or could form oxidation products for SOA formation, have been identified. Cyclic compounds are particularly important, including compounds such as cycloalkanes, aromatic hydrocarbons, and terpenes. Terpenes are typically oxidized by an addition mechanism, yielding oxidation products with more than two polar functional groups, and increasing the possibility of forming low-volatility products (Hallquist et al., 2009). A number of studies have focused on the oxidation pathways of monoterpenes by hydroxyl radical $(\mathrm{OH})$, ozone $\left(\mathrm{O}_{3}\right)$ or nitrate radical $\left(\mathrm{NO}_{3}\right)$ forming organic acids (such as pinonic and pinic acid) as supposed first-generation oxidation products (Glasius et al., 2000; Larsen et al., 2001; Yu et al., 1999; Hoffmann et al., 1997; Librando and Tringali, 2005; Surratt et al., 2008b; Calogirou et al., 1999; Yasmeen et al., 2012). The first-generation products are further oxidized to form more oxidized products, for example, pinonic acid is oxidized by the $\mathrm{OH}$ radical to form 3-methyl-1,2,3butanetricarboxylic acid (MBTCA) (Szmigielski et al., 2007; Müller et al., 2012). Another example is the photooxidation and ozonolysis of $\alpha$-pinene, one of the principal species of the monoterpene class, forming terpenylic acid and diaterpenylic acid acetate (DTAA) (Claeys et al., 2009).

Organosulfate formation has recently been demonstrated in both laboratory studies (Surratt et al., 2007a, 2008b; Iinuma et al., 2007b) and ambient samples (Gómez-González et al., 2008, 2012; Kristensen and Glasius, 2011; Worton et al., 2011) as SOA produced from the oxidation of biogenic VOC, such as isoprene, $\alpha$-pinene, $\beta$-pinene and limonene in the presence of acidic sulfate particles. In addition to representing an interesting link that couples the formation of SOA from biogenic VOC precursors with the impact from anthropogenic pollutants, organosulfates were also estimated to contribute up to $5-10 \%$ of the total organic mass (Tolocka and Turpin, 2012) or even $30 \%$ of the total aerosol mass (Surratt et al., 2008b). Organosulfates and nitrooxy organosulfates are also polar compounds, which can thus enhance the ability of aerosols to act as cloud condensation nuclei $(\mathrm{CCN})$ with important climate implications (Hallquist et al., 2009; IPCC, 2007).

Here we studied the occurrence, concentrations and trends of the acidic monoterpene oxidation products (including for example cis-pinic acid, pinonic acid, terpenylic acid, MTBCA and DTAA), oxidation products from anthropogenic VOC precursors, benzoic acid and phthalic acid (typically from aromatic hydrocarbons) or adipic acid and pimelic acid (from cyclic olefins), organosulfates, and nitrooxy organosulfates in aerosols at two different locations in Denmark. These include an urban curbside site and a semi-rural background site. The chemical analysis was performed following an approach adapted from Kristensen and Glasius (2011), employing high-performance liquid chromatography (HPLC) coupled with an electrospray ionization inlet (ESI) to a quadrupole time-of-flight mass spectrometer (q-TOF-MS). The impacts of long-range-transported SOA were investigated using the Hybrid Single Particle Lagrangian Integrated Trajectory (HYSPLIT) model assisted by the modeled emissions of the major biogenic precursors, including isoprene and monoterpene using the global Model of Emissions of Gases and Aerosols from Nature (MEGAN) and the anthropogenic emissions of sulfur dioxide $\left(\mathrm{SO}_{2}\right)$ using the long-range chemistry transport model, the Danish Eulerian Hemispheric Model (DEHM), based on the European Monitoring and Evaluation Program (www.EMEP.int) database. Additional support analyses were also performed, including measurement of major inorganic ions to determine the aerosol acidity level, analysis of local new particle formation events, local concentrations of atmospheric oxidants including ozone $\left(\mathrm{O}_{3}\right), \mathrm{SO}_{2}$ and nitrogen oxides $\mathrm{NO}_{\mathrm{x}}$ $\left(\mathrm{NO}_{\mathrm{x}}=\mathrm{NO}+\mathrm{NO}_{2}\right)$ and other meteorological parameters including the global radiation level, temperature, relative humidity $(\mathrm{RH})$, wind direction and wind speed.

\section{Experimental}

\subsection{Field campaign sites}

The campaign was concurrently conducted during the period of 19 May-22 June, 2011 at two sampling sites in Denmark (Fig. 1). The sampling site $\operatorname{HCAB}\left(55^{\circ} 38^{\prime} \mathrm{N}, 12^{\circ} 34^{\prime} \mathrm{E}\right)$ is located in central Copenhagen ( $\sim 1.2$ million inhabitants) on the curbside of H.C. Andersens Boulevard with considerable traffic influence $(\sim 50000$ vehicles per day) (Municipality 
of Copenhagen, www.kk.dk). The second sampling site Ris $\varnothing$ $\left(55^{\circ} 41^{\prime} \mathrm{N}, 12^{\circ} 05^{\prime} \mathrm{E}\right)$ is a semi-rural background site located approximately $30 \mathrm{~km}$ west of Copenhagen and $7 \mathrm{~km}$ northeast of Roskilde, which houses about 46000 inhabitants. The semi-rural background area is characterized by agricultural land, small villages, Roskilde Fjord (located about $100 \mathrm{~m}$ to the west of the station) and a main road (A6) located about $700 \mathrm{~m}$ east of the site. $\mathrm{PM}_{1}$ samples were collected on quartz fiber filters (150 mm diameter, Advantec QR-100) using Digitel DHA-80 High Volume Samplers (HVS) equipped with $\mathrm{PM}_{1}$ sampling heads. The quartz fiber filters were pre-baked at $1000^{\circ} \mathrm{C}$ for $2 \mathrm{~h}$ by the manufacturer to reduce organic contamination and kept in sealed bag until use. In order to assess the diurnal variation on $\mathrm{PM}_{1}$ composition, sampling was performed in $12 \mathrm{~h}$ daytime and nighttime intervals simultaneously starting every day at 6 a.m. and $6 \mathrm{p} . \mathrm{m}$. local time at both sites. The sampling flow rate was set to $23.1 \mathrm{~m}^{3} \mathrm{~h}^{-1}$ providing a nominal sampling volume of $277.2 \mathrm{~m}^{3}$ per $12 \mathrm{~h}$ sample. While this $12 \mathrm{~h}$ sampling interval allowed us to sample a sufficient volume of the tracer compounds, the coarse time resolution complicates investigation of any short-term chemistry or transport episodes. There were several gaps in the data set, with one major gap at the Risø site from 3 to 16 June due to technical problems with the HVS. In total, 64 and 37 filter samples (including both day and night samples) were collected at $\mathrm{HCAB}$ and Ris $\emptyset$, respectively. A field blank was collected in between every 12 samples or less, which showed concentrations below detection limit for the organic acids, organosulfates and nitrooxy organosulfates. The field blanks were, however, used for correction of concentrations of inorganic ions. The sample and blank filters were wrapped in aluminum foil and stored in an anti-static bag at $-18^{\circ} \mathrm{C}$ in dark conditions until analysis.

\subsection{Extraction}

Extraction and analysis of organic acids, organosulfates and nitrooxy organosulfates followed the procedure of Kristensen and Glasius (2011). Each filter sample (excluding a circle punch of $28 \mathrm{~mm}$ in diameter used for separate analysis of ions) was extracted in $75 \mathrm{~mL}$ of a solution consisting of $90 \%(v / v)$ acetonitrile and $10 \%(v / v)$ milli-Q water by ultra-sonication for $30 \mathrm{~min}$ in a water bath, where ice was regularly added to the bath to avoid heating. The extract was filtered through a nylon syringe filter $(0.45 \mu \mathrm{m}$, VWR or Q$\max )$, evaporated to dryness using a rotary evaporator and re-constituted twice in $500 \mu \mathrm{L}$ milli-Q water containing $3 \%$ $(v / v)$ acetonitrile and $0.1 \%(v / v)$ acetic acid. Prepared samples were kept at $3-5{ }^{\circ} \mathrm{C}$ prior to analysis. Camphoric acid was used as an internal standard to calculate the recovery. Field blanks were extracted and analyzed using the same procedure as for the samples. It has been shown that the method could sufficiently retain more volatile compounds such as pinonic acid, as well as the less volatile compounds such as pinic, terpenylic and adipic acid (Kristensen and Glasius, 2011).

\subsection{HPLC-ESI-qTOF-MS analysis and quantification of compounds}

Samples were analyzed using a HPLC system (Dionex U1timate 3000) coupled through an ESI inlet to a qTOF-MS (Bruker Daltonics GmbH, Bremen, Germany). A reversedphase HPLC separation was achieved using a Waters Atlantis T3 C18 column $(2.1 \times 150 \mathrm{~mm}, 3 \mu \mathrm{m})$. The mobile phase was comprised of eluent A $(0.1 \%(v / v)$ acetic acid in milli-Q water) and eluent B (95\% $(v / v)$ acetonitrile in milli-Q water). The injection volume was $10 \mu \mathrm{L}$ and the flow rate of the mobile phase was $0.2 \mathrm{~mL} \mathrm{~min}^{-1}$ with the following gradient: the mobile phase was kept at $3 \%$ of eluent $B$ in the 10 min prior to injection until $5 \mathrm{~min}$ after injection; eluent $\mathrm{B}$ was then increased to $20 \%$ (at $20 \mathrm{~min}$ ), $60 \%$ (at $30 \mathrm{~min}$ ) and $95 \%$ (at $35 \mathrm{~min}$ ) where it was kept at a plateau $(95 \%)$ until $45 \mathrm{~min}$ and increased to $100 \%$ at $46 \mathrm{~min}$; the gradient was kept at $100 \%$ of eluent B until $51 \mathrm{~min}$ and decreased to $3 \%$ at $54 \mathrm{~min}$, where it was further kept at $3 \%$ for $3 \mathrm{~min}$. The MS scan range was set from 50 to $1000 \mathrm{~m} / \mathrm{z}$. The ESI-qTOF-MS was operated in negative ionization mode with nebulizer pressure at 3.0 bar, dry gas flow $8.0 \mathrm{~L} \mathrm{~min}^{-1}$, source voltage $4000 \mathrm{~V}$ and transfer time $50 \mu \mathrm{s}$. Acquired data were processed using the Bruker Compass software.

All organic acids were quantified using authentic standards with the exception of hydroxy-pinonic acid, which was quantified using pinonic acid standard. The organosulfates and nitrooxy organosulfates were quantified using three different surrogate standards, depending on the retention time of the compound. The surrogate standards included D-mannose sulfate (molecular weight $=260 \mathrm{~g} \mathrm{~mol}^{-1}$ (MW 260)) for compounds eluting in the first $15 \mathrm{~min}$, an organosulfate from $\beta$-pinene (MW 250), which was synthesized inhouse following Iinuma et al. (2009) for compounds eluting during the 15-40 min period, and octyl sulfate (MW 210) for compounds eluting after $40 \mathrm{~min}$.

\subsection{Extraction and analysis of ions}

A circle punch (28 mm diameter) of the aerosol sample filter was sonicated in $4.00 \mathrm{~mL}$ milli-Q water for half an hour. The extract was filtered through a polyethersulfone syringe filter $(0.45 \mu \mathrm{m}$, PALL Life Sciences IC Acrodisc) and analyzed by ion chromatography using a Metrohm 820 IC separation center (with a Metrosep A Supp5-150 column for anion analysis and a Metrosep C4-150 column for cation analysis) and an 819 IC conductivity detector. For anion analysis, an eluent of $3.2 \mathrm{mM} \mathrm{Na} 2 \mathrm{CO}_{3} / 1.0 \mathrm{mM} \mathrm{NaHCO} 3$ was used. For cation analysis, an eluent of $0.7 \mathrm{mM}$ dipicolinic acid/1.7 $\mathrm{mM} \mathrm{HNO}_{3}$ was used. An auto-sampler was used where $100 \mu \mathrm{L}$ of each sample was introduced into the eluent, which was kept at a flow rate of $0.7 \mathrm{~mL} \mathrm{~min}^{-1}$. The inclusion of ion analysis in 


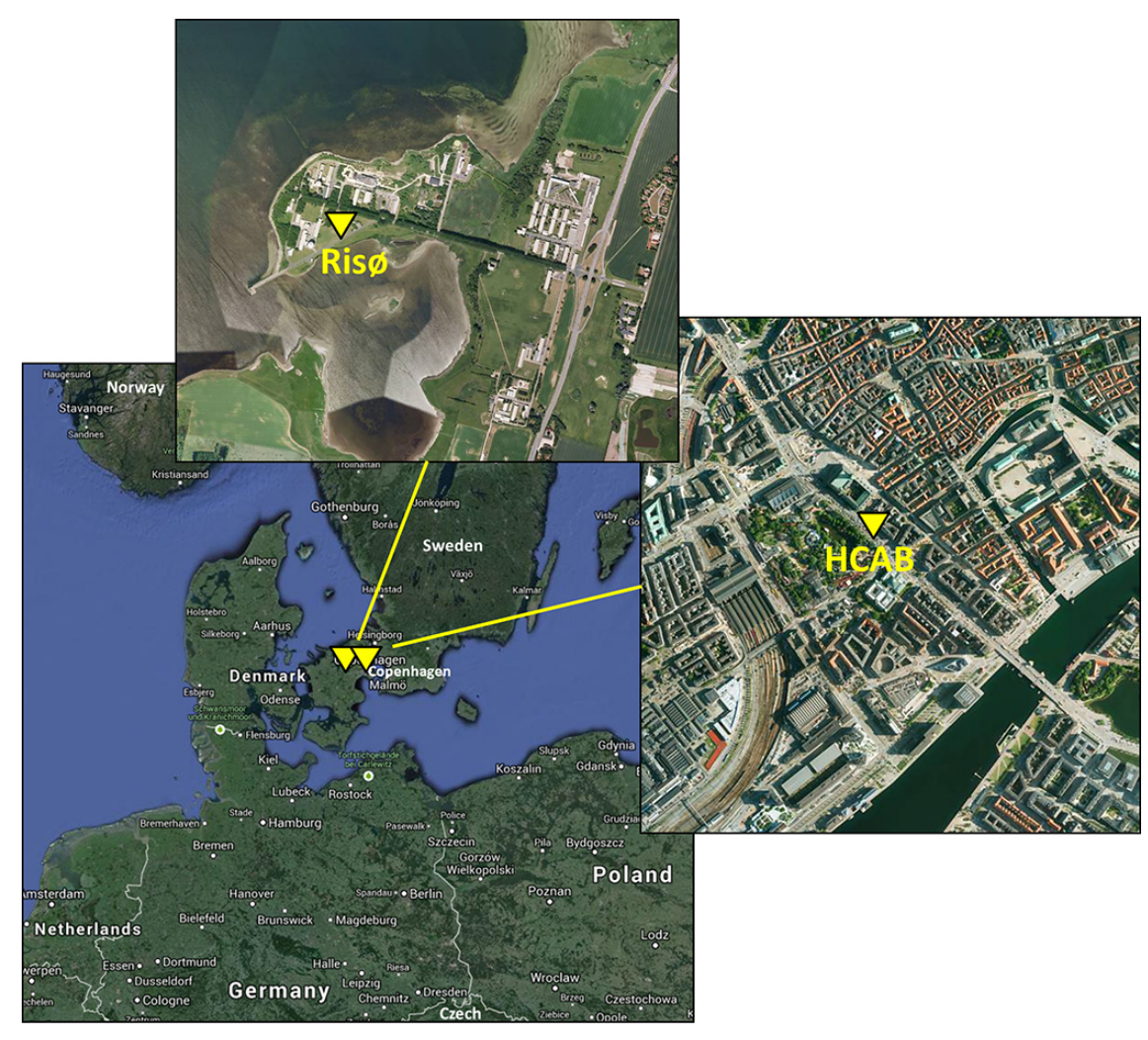

Figure 1. Locations of the urban curbside station H.C. Andersens Boulevard (HCAB) and the semi-rural background station (Ris $\varnothing$ ) (map. krak.dk and map.google.dk). HCAB is located in the city center of Copenhagen close to a busy street. Ris $\emptyset$ is located approximately $30 \mathrm{~km}$ west of $\mathrm{HCAB}$.

this work is mainly to calculate the level of acidity $\left(\mathrm{H}^{+}\right)$from the charge balance, based on IC data of $\left[\mathrm{SO}_{4}^{2-}\right],\left[\mathrm{NO}_{3}^{-}\right]$and $\left[\mathrm{NH}_{4}^{+}\right]$following Zhang et al. (2012b).

\subsection{Measurement of particle number size distributions}

Particle number size distributions in 15 channels from 6 to $700 \mathrm{~nm}$ were measured using a Differential Mobility Particle Sizer (DMPS), which was composed of a Vienna-type Differential Mobility Analyzer (DMA) (Winklmayer et al., 1991) employing re-circulating sheath air flow (Jokinen and Makela, 1997) and a butanol Condensation Particle Counter (CPC) (TSI Inc. 3010, Shoreview, MN). The data were corrected for reduced counting efficiency at the low size end (6$10 \mathrm{~nm}$ ), multiple charging, and losses during sampling following an inversion algorithm by Wiedensohler (1988). A ratio of sheath air to aerosol air of $6.8: 1$ was applied, with alternating up- and down-scans of $150 \mathrm{~s}$ for each size spectrum. Annual service of the CPC was performed at TSI to ensure correct counting efficiency.

\subsection{Biogenic VOC and $\mathrm{SO}_{2}$ emissions}

Emissions of biogenic VOCs are estimated by using the global model MEGAN (Guenther et al., 2006; Zare et al.,
2012, 2014). The empirical algorithm in MEGAN simulates the emission rates based on relationships between ecosystem-dependent emission factors and key drivers that control emissions. The model takes into account the effects of temperature, radiation, leaf area index, foliage age and soil moisture on the estimation of emissions. In MEGAN, plant species are grouped into six plant functional types (PFTs): broadleaf tree, needle leaf evergreen tree, needle leaf deciduous tree, shrub, crop and grass; the model data set provides the geographical distribution of the standard emission factor of the six PFTs with a high spatial resolution of $1 \mathrm{~km}^{2}$. The required meteorological inputs are provided by the MM5v3.7 model (Grell et al., 1994). The initial and boundary conditions for the MM5 model are derived from the National Center for Environmental Prediction (NCEP) FNL (Final Analyses) data with $6 \mathrm{~h}$ temporal and $1^{\circ} \times 1^{\circ}$ spatial resolution (http://rda.ucar.edu/datasets/ds083.2/).

Sulfur dioxide emissions were modeled using the longrange chemistry transport model, the Danish Eulerian Hemispheric Model (DEHM) (Brandt et al., 2012), based on the European Monitoring and Evaluation Program (www.EMEP. int) database in Europe with a resolution of $50 \mathrm{~km} \times 50 \mathrm{~km}$. These European anthropogenic sulfur dioxide emissions are mainly released by fuel combustion (www.ceip.at), 
dominated by coal-fired power plants and international ship traffic emissions.

\subsection{Gas and meteorological data}

Meteorological data including temperature, $\mathrm{RH}$ and global radiation were obtained from a station located on the rooftop of the H.C. Ørsted institute (HCOE, $55^{\circ} 42^{\prime} \mathrm{N}, 12^{\circ} 33^{\prime} \mathrm{E}$ ), which represents the urban background conditions of Copenhagen, Denmark. HCOE is located $\sim 3.5 \mathrm{~km}$ north of HCAB. $\mathrm{O}_{3}$ and $\mathrm{NO} / \mathrm{NO}_{\mathrm{x}}$ were respectively measured using photometry (Teledyne API 400, San Diego, CA, USA), chemiluminescence (Teledyne API M200 A, San Diego, CA, USA) and infrared absorbance (Teledyne API 300 E, San Diego, CA, USA), at both field sites HCAB and Ris $\varnothing$ with 30 min resolution, whereas the measurement of $\mathrm{SO}_{2}$ using UV fluorescence (Teledyne API M100E, San Diego, CA, USA) with 30 min resolution was only obtained from $\mathrm{HCAB}$. Gas and meteorological data were collected within the Danish Air Quality Monitoring Program (Ellermann et al., 2012). As nitrate radical is formed in the reaction

$\mathrm{NO}_{2}+\mathrm{O}_{3} \rightarrow \mathrm{NO}_{3}+\mathrm{O}_{2}$,

the production rate of $\mathrm{NO}_{3}\left(P_{\mathrm{NO}_{3}}\right)$ was determined from the measured concentrations of $\mathrm{NO}_{2}$ and $\mathrm{O}_{3}$ using Eq. (1):

$P_{\mathrm{NO}_{3}}=\left[\mathrm{NO}_{2}\right]\left[\mathrm{O}_{3}\right] k_{1}$ molecule $\mathrm{cm}^{-3} \mathrm{~s}^{-1}$.

The rate constant of Reaction (R1) $k_{1}$ was calculated using Eq. (2) with available temperature data (DeMore, 1997):

$k_{1}=1.2 \times 10^{-13} e^{-\frac{2450}{T}} \mathrm{~cm}^{3}$ molecule ${ }^{-1} \mathrm{~s}^{-1}$.

\subsection{Statistical analysis}

Statistical analysis was performed on the data set to analyze the intraday variability between daytime and nighttime samples as well as the possible inter-site variation between the two sites HCAB and Ris $\varnothing$. As the data were not normally distributed, the $U$ Mann-Whitney test was used instead of a two-way ANOVA to assess the intraday and inter-site variability (Wilks, 2011).

\section{Results and discussion}

\subsection{Detection and characterization of organic acids, organosulfates and nitrooxy organosulfates}

During the field campaign, a total of 39 species, including 12 organic acids, 18 organosulfates (OS) and 9 nitrooxy organosulfates (NOS), were detected as summarized in Tables 1-3. The organic acids were identified using their authentic standards, with the exception of hydroxy-pinonic acid where the identification was based on the characteristic mass-to-charge $(\mathrm{m} / \mathrm{z})$ fragments of the compound. The organic acids included those of anthropogenic origin (i.e., benzoic acid, adipic acid, pimelic acid and phthalic acid) and biogenic origin, specifically suberic acid and azelaic acid originating from unsaturated fatty acids, in addition to terpenylic acid, pinonic acid, pinic acid, hydroxy-pinonic acid, DTAA and MTBCA originating from $\alpha / \beta$-pinene (Table 1 ). Among the anthropogenic organic acids, benzoic acid is a photochemical degradation product of aromatic hydrocarbons, which originate from anthropogenic automobile emissions (Suh et al., 2003), while adipic acid and pimelic acid have been identified as photooxidation products from the ozonolysis of cyclic olefins (Hatakeyama et al., 1985; Grosjean et al., 1978; Koch et al., 2000); and phthalic acid could be the oxidation product of naphthalene and other polycyclic aromatic compounds (Fine et al., 2004). The biogenic dicarboxylic acids with relatively long carbon chains, including suberic acid $\left(C_{8}\right)$ and azelaic acid $\left(C_{9}\right)$, are believed to originate from the oxidation of unsaturated fatty acids (Mochida et al., 2003), which are common in marine phytoplankton and leaves of terrestrial higher plants, though some contribution may originate from anthropogenic meat cooking (Rogge et al., 1991) or wood burning (Rogge et al., 1998). The other biogenic organic acids (terpenylic acid, pinonic acid, pinic acid, hydroxy-pinonic acid and DTAA) are oxidation products of $\alpha / \beta$-pinene (Claeys et al., 2009; Ma et al., 2007), with 3-methyl-1,2,3-butanetricarboxylic acid (MBTCA) being the second-generation oxidation product of pinonic acid, which indicates aging by $\mathrm{OH}$ (Müller et al., 2012; Szmigielski et al., 2007). The identified organic acids were all detected at both sites.

The organosulfates were identified using the characteristic fragment of $m / z 97$ (bisulfate anion $\mathrm{HSO}_{4}^{-}$) and $m / z 80$ (sulfur trioxide anion $\mathrm{SO}_{3}^{-}$). The nitrooxy organosulfates were identified based on a neutral loss of $m / z 63\left(\mathrm{HNO}_{3}\right)$ in addition to the characteristic fragments of $\mathrm{HSO}_{4}^{-}$and $\mathrm{SO}_{3}^{-}$. Many organosulfates and nitrooxy organosulfates species detected in this study (Tables 2 and 3) have also been identified in a previous smog chamber (Surratt et al., 2007a, 2008b, 2010) and field studies (Gómez-González et al., 2008, 2012; Kristensen and Glasius, 2011). Most organosulfates, which were identified based on the literature, probably originated from isoprene (OS molecular weight (MW) 154, 156, $170,212,214,216$ and 334) and monoterpenes including $\alpha$ - and $\beta$-pinene precursors (OS 248, 250, 280 and 298). Two organosulfates of MW 200 were identified, of which OS 200_1 could originate from isoprene via methacrylic acid epoxide (MAE) uptake onto acidified sulfate aerosol (Lin et al., 2013), while OS 200_2 could derive from 2methyl-3-buten-2-ol (MBO) (Zhang et al., 2012b, 2014). A large share of the detected nitrooxy organosulfates could be the oxidation products from limonene and/or monoterpenes (NOS 297, 311, 313, 327 and 329). The structures of several organosulfates (OS 182, OS 208, and OS 210) and one nitrooxy organosulfate (NOS 331) were not identified. 
Table 1. Detected organic acids during the campaign. Related references on suggested precursors are cited in the text.

\begin{tabular}{|c|c|c|c|c|c|}
\hline Organic acid & $\begin{array}{r}{[\mathrm{M}-\mathrm{H}]^{-} \text {ion }} \\
(\mathrm{m} / \mathrm{z})\end{array}$ & $\begin{array}{r}\text { Retention time } \\
(\mathrm{min})\end{array}$ & $\begin{array}{l}\text { Proposed molecular } \\
\text { formula }\end{array}$ & $\begin{array}{l}\text { Proposed } \\
\text { structure }\end{array}$ & $\begin{array}{l}\text { Suggested } \\
\text { precursors }\end{array}$ \\
\hline Benzoic acid & 121.022 & 27.5 & $\mathrm{C}_{7} \mathrm{H}_{6} \mathrm{O}_{2}$ & & Aromatic hydrocarbons \\
\hline Adipic acid & 145.058 & 14.9 & $\mathrm{C}_{6} \mathrm{H}_{10} \mathrm{O}_{4}$ & & Cyclic olefins \\
\hline Pimelic acid & 159.061 & 20.3 & $\mathrm{C}_{7} \mathrm{H}_{12} \mathrm{O}_{4}$ & & Cyclic olefins \\
\hline Phthalic acid & 165.123 & 19.0 & $\mathrm{C}_{8} \mathrm{H}_{6} \mathrm{O}_{4}$ & & Aromatic hydrocarbons \\
\hline Terpenylic acid & 171.058 & 18.3 & $\mathrm{C}_{8} \mathrm{H}_{12} \mathrm{O}_{4}$ & & $\alpha$-pinene \\
\hline Suberic acid & 173.074 & 25.4 & $\mathrm{C}_{8} \mathrm{H}_{14} \mathrm{O}_{4}$ & & Fatty acids \\
\hline Pinonic acid & 183.100 & 27.5 & $\mathrm{C}_{10} \mathrm{H}_{16} \mathrm{O}_{3}$ & & $\alpha / \beta$-pinene \\
\hline Pinic acid & 185.077 & $23.0 ; 24.0$ & $\mathrm{C}_{9} \mathrm{H}_{14} \mathrm{O}_{4}$ & & $\alpha / \beta$-pinene \\
\hline Azelaic acid & 187.091 & 28.1 & $\mathrm{C}_{9} \mathrm{H}_{16} \mathrm{O}_{4}$ & & Fatty acids \\
\hline Hydroxy-pinonic acid & 199.092 & 29.0 & $\mathrm{C}_{10} \mathrm{H}_{16} \mathrm{O}_{4}$ & & $\alpha / \beta$-pinene \\
\hline 3-Methyl-1,2,3-butanetricarboxylic acid (MBTCA) & 203.050 & 16.2 & $\mathrm{C}_{8} \mathrm{H}_{12} \mathrm{O}_{6}$ & & $\alpha / \beta$-pinene \\
\hline Di-terpenylic acid acetate (DTAA) & 231.220 & 24.3 & $\mathrm{C}_{10} \mathrm{H}_{16} \mathrm{O}_{6}$ & & $\alpha$-pinene \\
\hline
\end{tabular}

\subsection{Concentrations}

The ranges of concentration levels of the detected species are shown in Table 4. In general, a higher number of valid measurements $(N)$ were available from $\mathrm{HCAB}$, mostly due to the gap in the set of samples collected from the semi-rural background site Risø. The total concentrations of the detected organic acids averaged per sampling interval $(12 \mathrm{~h})$ during the sampling period was $23 \pm 15 \mathrm{ng} \mathrm{m}^{-3}$ and $19 \pm 13 \mathrm{ng} \mathrm{m}^{-3}$ at $\mathrm{HCAB}$ and Ris $\varnothing$, respectively, with the second-generation product MBTCA accounting for approximately $21 \%$ of total organic acids at $\mathrm{HCAB}$ and $20 \%$ at Ris $\varnothing$. The median value of MBTCA was $2.3 \mathrm{ng} \mathrm{m}^{-3}$ at HCAB and $2.0 \mathrm{ng} \mathrm{m}^{-3}$ at Ris $\emptyset$, which are in range of the overall median value of $2.7 \mathrm{ng} \mathrm{m}^{-3}$ reported by Gómez-González et al. (2012) from a study at a Belgian forest site with severe urban pollution impact. Among the anthropogenic organic acids, adipic acid and phthalic acid seemed to dominate at both sites, whereas azelaic acid (4.0 $\mathrm{ng} \mathrm{m}^{-3}$ average) and pinonic acid (2.2 $\mathrm{ng} \mathrm{m}^{-3}$ average) were the dominant first-generation biogenic organic acid at HCAB and Ris $\varnothing$, respectively.
The organosulfates were detected in most samples from both sites (Table 4). The major organosulfates detected in high concentrations at both HCAB and Ris $\varnothing$ mostly originated from isoprene, such as OS 154, OS 156, OS 200 and OS 212 (Surratt et al., 2007a, 2008b). OS 216, which was suggested to derive from the reactive uptake of isoprene epoxydiols (IEPOX) in the presence of acidic sulfate aerosol (Surratt et al., 2010; Lin et al., 2012), tends to be the most abundant organosulfate observed in prior laboratory studies and field studies in the southeastern US (Surratt et al., 2007b, 2008a, 2010; Lin et al., 2012, 2013). In this study, a moderate mean concentration of OS 216 of $5 \mathrm{ng} \mathrm{m}^{-3}$ at $\mathrm{HCAB}$ and $3.2 \mathrm{ng} \mathrm{m}^{-3}$ at Ris $\varnothing$ was observed. It should also be noted that we used acetonitrile as an extraction solvent instead of methanol as used by Surratt et al. (2007b, 2008, 2010) and Lin et al. (2012, 2013), which could have affected the extraction yield of OS 216 in the present work. The total organosulfate concentration averaged per sampling interval (12 h) during the sampling period was $60 \pm 45 \mathrm{ng} \mathrm{m}^{-3}$ at $\mathrm{HCAB}$, whereas at Ris $\varnothing$ a slightly lower total concentration value of $47 \pm 31 \mathrm{ng} \mathrm{m}^{-3}$ was obtained. Nitrooxy organosulfates were detected in lower concentrations compared to 
Table 2. Detected organosulfates (OS) during the campaign.

\begin{tabular}{|c|c|c|c|c|c|}
\hline Organosulfate & $\begin{array}{r}{[\mathrm{M}-\mathrm{H}]^{-} \text {ion }} \\
(m / z)\end{array}$ & $\begin{array}{r}\text { Retention time } \\
(\mathrm{min})\end{array}$ & $\begin{array}{l}\text { Proposed molecular } \\
\text { formula }\end{array}$ & $\begin{array}{l}\text { Proposed } \\
\text { structure }\end{array}$ & $\begin{array}{l}\text { Suggested } \\
\text { precursors }\end{array}$ \\
\hline OS $154^{1,2}$ & 152.981 & $3.6 ; 6.7$ & $\mathrm{C}_{3} \mathrm{H}_{6} \mathrm{O}_{5} \mathrm{~S}$ & & hydroxyacetone (isoprene) \\
\hline OS $156^{3}$ & 154.957 & 2.8 & $\mathrm{C}_{2} \mathrm{H}_{4} \mathrm{O}_{6} \mathrm{~S}$ & & glyoxal \\
\hline $\begin{array}{l}\text { OS } 170^{4} \\
\text { OS } 182\end{array}$ & $\begin{array}{l}169.047 \\
181.063\end{array}$ & $\begin{array}{r}3.4 \\
34.8\end{array}$ & $\begin{array}{l}\mathrm{C}_{3} \mathrm{H}_{6} \mathrm{O}_{6} \mathrm{~S} \\
\mathrm{C}_{5} \mathrm{H}_{10} \mathrm{O}_{5} \mathrm{~S}\end{array}$ & $\begin{array}{l}\text { Ho' } \\
\text { unk }\end{array}$ & $\begin{array}{l}\text { methylglyoxal } \\
\text { unknown }\end{array}$ \\
\hline OS 200_1 1 & 198.998 & 3.3 & $\mathrm{C}_{4} \mathrm{H}_{8} \mathrm{O}_{7} \mathrm{~S}$ & & 2-methylglyceric acid (isoprene) ${ }^{9}$ \\
\hline $\begin{array}{l}\text { OS } 200 \_2^{5,6} \\
\text { OS } 208 \\
\text { OS } 210 \\
\text { OS } 212^{2} \\
\text { OS } 214^{2,7,8}\end{array}$ & $\begin{array}{l}199.001 \\
207.101 \\
209.086 \\
210.983 \\
213.001\end{array}$ & $\begin{array}{r}3.4 \\
28.4 ; 29.5 \\
28.0 ; 30.5 \\
4.8 \\
3.5\end{array}$ & $\begin{array}{l}\mathrm{C}_{5} \mathrm{H}_{12} \mathrm{O}_{6} \mathrm{~S} \\
\mathrm{C}_{6} \mathrm{H}_{8} \mathrm{O}_{6} \mathrm{~S} \\
\mathrm{C}_{7} \mathrm{H}_{14} \mathrm{O}_{5} \mathrm{~S} \\
\mathrm{C}_{5} \mathrm{H}_{8} \mathrm{O}_{7} \mathrm{~S} \\
\mathrm{C}_{5} \mathrm{H}_{10} \mathrm{O}_{7} \mathrm{~S}\end{array}$ & $\begin{array}{l}\text { unknown } \\
\text { unknown } \\
\text { unknown } \\
\text { unknown }\end{array}$ & $\begin{array}{l}\text { 2-methyl-3-buten-2-ol (MBO) } \\
\text { unknown } \\
\text { unknown } \\
\text { isoprene } \\
\text { isoprene }^{2,5}\end{array}$ \\
\hline $\begin{array}{l}\text { OS } 216^{1,2} \\
\text { OS } 248^{2}\end{array}$ & $\begin{array}{l}215.018 \\
247.061\end{array}$ & $\begin{array}{r}2.9 \\
32.2\end{array}$ & $\begin{array}{l}\mathrm{C}_{5} \mathrm{H}_{12} \mathrm{O}_{7} \mathrm{~S} \\
\mathrm{C}_{10} \mathrm{H}_{16} \mathrm{O}_{5} \mathrm{~S}\end{array}$ & $\begin{array}{l}\mathrm{OH} \quad \mathrm{OH} \\
\text { unknown }\end{array}$ & $\begin{array}{l}\text { 2-methyltetrols (isoprene) }{ }^{10} \\
\alpha \text {-pinene }\end{array}$ \\
\hline OS $250^{2}$ & 249.074 & 31.6 & $\mathrm{C}_{10} \mathrm{H}_{18} \mathrm{O}_{5} \mathrm{~S}$ & & $\beta$-pinene ${ }^{11}$ \\
\hline $\begin{array}{l}\text { OS } 252^{2} \\
\text { OS } 254^{2}\end{array}$ & $\begin{array}{l}251.017 \\
253.158\end{array}$ & $\begin{array}{l}15.3 \\
21.3\end{array}$ & $\begin{array}{l}\mathrm{C}_{9} \mathrm{H}_{16} \mathrm{O}_{6} \mathrm{~S} \\
\mathrm{C}_{8} \mathrm{H}_{14} \mathrm{O}_{7} \mathrm{~S}\end{array}$ & wn & $\begin{array}{l}\text { limonene } \\
\alpha \text {-terpinene }\end{array}$ \\
\hline OS $268^{2}$ & 267.225 & 19.7 & $\mathrm{C}_{9} \mathrm{H}_{16} \mathrm{O}_{7} \mathrm{~S}$ & & limonene \\
\hline OS $280^{2}$ & 279.046 & $22.5 ; 25.2$ & $\mathrm{C}_{10} \mathrm{H}_{16} \mathrm{O}_{7} \mathrm{~S}$ & & $\alpha / \beta$-pinene \\
\hline OS $298^{2}$ & 297.079 & 25.5 & $\mathrm{C}_{10} \mathrm{H}_{18} \mathrm{O}_{8} \mathrm{~S}$ & & $\alpha$-pinene \\
\hline OS $334^{2}$ & 333.071 & 38.0 & $\mathrm{C}_{10} \mathrm{H}_{22} \mathrm{O}_{10} \mathrm{~S}$ & $\mathrm{DH}$ & isoprene \\
\hline
\end{tabular}


Table 3. Detected nitrooxy organosulfates (NOS) during the campaign.

\begin{tabular}{|c|c|c|c|c|c|}
\hline $\begin{array}{l}\text { Nitrooxy } \\
\text { organosulfate }\end{array}$ & $\begin{array}{r}{[\mathrm{M}-\mathrm{H}]^{-} \text {ion }} \\
(m / z)\end{array}$ & $\begin{array}{r}\text { Retention time } \\
(\mathrm{min})\end{array}$ & $\begin{array}{l}\text { Proposed molecular } \\
\text { formula }\end{array}$ & $\begin{array}{l}\text { Proposed } \\
\text { structure }\end{array}$ & $\begin{array}{l}\text { Suggested } \\
\text { precursors }\end{array}$ \\
\hline NOS $295^{2}$ & 294.063 & $42.1 ; 44.7$ & $\mathrm{C}_{10} \mathrm{H}_{17} \mathrm{NO}_{7} \mathrm{~S}$ & More isomers & $\alpha / \beta$-pinene \\
\hline NOS $297^{2}$ & 296.063 & 32.8 & $\mathrm{C}_{9} \mathrm{H}_{15} \mathrm{NO}_{8} \mathrm{~S}$ & & limonene \\
\hline NOS $311^{2}$ & 310.088 & 38.0 & $\mathrm{C}_{10} \mathrm{H}_{17} \mathrm{NO}_{8} \mathrm{~S}$ & & limonene, $\alpha$-pinene \\
\hline NOS $313^{2}$ & 312.209 & 28.0 & $\mathrm{C}_{9} \mathrm{H}_{15} \mathrm{NO}_{9} \mathrm{~S}$ & nown & limonene \\
\hline NOS $327^{2}$ & 326.279 & 26.8 & $\mathrm{C}_{10} \mathrm{H}_{17} \mathrm{NO}_{9} \mathrm{~S}$ & & limonene, $\beta$-pinene, terpinolene \\
\hline NOS $329^{2}$ & 327.994 & 33.5 & $\mathrm{C}_{10} \mathrm{H}_{19} \mathrm{NO}_{9} \mathrm{~S}$ & & limonene \\
\hline NOS $331^{2}$ & 330.002 & 15.6 & $\mathrm{C}_{9} \mathrm{H}_{17} \mathrm{NO}_{10} \mathrm{~S}$ & unknown & unknown \\
\hline NOS $340^{2}$ & 339.070 & 25.7 & $\mathrm{C}_{10} \mathrm{H}_{16} \mathrm{~N}_{2} \mathrm{O}_{9} \mathrm{~S}$ & unknown & $\alpha$-pinene \\
\hline NOS $343^{2}$ & 342.043 & 38.8 & $\mathrm{C}_{10} \mathrm{H}_{17} \mathrm{NO}_{10} \mathrm{~S}$ & unknown & $\alpha$-pinene; $\alpha$-terpinene \\
\hline
\end{tabular}

References include ${ }^{1}$ Surratt et al. (2007a); ${ }^{2}$ Surratt et al. (2008b); ${ }^{3}$ Surratt et al. (2010); ${ }^{4}$ Gómez-González et al. (2008); ${ }^{5}$ Kristensen and Glasius (2011).

organosulfates, with a total concentration of $4 \pm 1 \mathrm{ng} \mathrm{m}^{-3}$ at $\mathrm{HCAB}$ and $3 \pm 1 \mathrm{ng} \mathrm{m}^{-3}$ at Risø. NOS 297, which was possibly an oxidation product from limonene (Surratt et al., 2008b) was the major nitrooxy organosulfate found at both sites.

The concentration levels of the detected compounds were compared with an earlier study performed at a forest site in Denmark by Kristensen and Glasius (2011) during spring 2008, in which fewer species (six organic acids, five organosulfate and five nitrooxy organosulfates) were included. The comparison was thus only targeted at the overlapped compounds. In general, the concentrations of most organic acids were higher in the present study, except cispinic acid and pinonic acid, which were more abundant at the forest site. The concentration levels of the organosulfates and nitrooxy organosulfates in this study were manyfold higher compared to the previous study, especially with regards to the organosulfate species. This, in addition to the differences among the sites and years could be caused by differences in quantification standards, as Kristensen and Glasius (2011) used camphor sulfonic acid as a surrogate standard, as opposed to the three different standards including D-mannose sulfate, an in-house synthesized organosul- fate from $\beta$-pinene and octyl sulfate used in this study (as described above). This highlights the analytical challenge of quantifying organosulfates and comparing concentrations among different studies.

The total concentration of organic acids and organosulfates are significantly higher in our samples compared to the Arctic, where a total concentration of $3 \pm 1 \mathrm{ng} \mathrm{m}^{-3}$ for organic acids and $12 \pm 2 \mathrm{ng} \mathrm{m}^{-3}$ for organosulfates (quantified using the same organosulfate from $\beta$-pinene used in the present study) were measured at Zeppelin Mountain, Svalbard, during summer of 2008 (Hansen et al., 2014). However, during late winter and early spring, total concentration levels up to 70 and over $45 \mathrm{ng} \mathrm{m}^{-3}$ were detected for all organic acid, organosulfate and nitrooxy organosulfate compounds, respectively, at Station Nord, northeast Greenland and at Zeppelin (Hansen et al., 2014). These values are in range with our concentration values. It must be noted that a total of 11 organic acids, 12 organosulfates and 1 nitrooxy organosulfate were detected by Hansen et al. (2014). 
Table 4. Concentration range $\left(\mathrm{ng} \mathrm{m}^{-3}\right)$ of the detected species at HCAB and Ris $\varnothing$, reported as mean, standard deviation (SD), median, max and the number of detected samples $(N)$ at each site.

\begin{tabular}{|c|c|c|c|c|c|c|c|c|c|c|}
\hline \multirow[t]{2}{*}{ Compound } & \multicolumn{5}{|c|}{ HCAB } & \multicolumn{5}{|c|}{ Risø } \\
\hline & Mean & $\mathrm{SD}$ & Median & $\operatorname{Max}$ & $N$ & Mean & $\mathrm{SD}$ & Median & Max & $N$ \\
\hline Benzoic acid & 0.4 & 0.6 & 0.1 & 2.0 & 14 & 1.4 & 1.9 & 0.4 & 7.2 & 26 \\
\hline Adipic acid & 3.3 & 1.4 & 2.8 & 8.4 & 64 & 2.9 & 1.1 & 2.8 & 5.9 & 38 \\
\hline Pimelic acid & 0.6 & 0.3 & 0.5 & 2.1 & 64 & 0.4 & 0.2 & 0.4 & 1.2 & 38 \\
\hline Phthalic acid & 5.6 & 2.3 & 5.1 & 13.0 & 64 & 4.3 & 1.8 & 4.4 & 10.4 & 38 \\
\hline Terpenylic acid & 1.6 & 1.6 & 1.1 & 8.9 & 64 & 1.4 & 1.7 & 0.9 & 8.5 & 38 \\
\hline Suberic acid & 1.1 & 0.6 & 1.0 & 3.7 & 64 & 0.9 & 0.5 & 0.8 & 2.9 & 38 \\
\hline Pinonic acid & 1.3 & 1.5 & 0.9 & 10.8 & 64 & 2.2 & 2.9 & 1.3 & 16.4 & 38 \\
\hline cisPinic acid & 0.5 & 0.5 & 0.4 & 3.9 & 64 & 0.6 & 0.9 & 0.4 & 5.6 & 37 \\
\hline Azelaic acid & 4.0 & 3.3 & 3.0 & 19.6 & 58 & 1.6 & 0.8 & 1.6 & 4.3 & 35 \\
\hline Hydroxy-pinonic acid & 0.1 & 0.1 & 0.1 & 0.2 & 12 & 0.1 & 0.0 & 0.1 & 0.1 & 4 \\
\hline MBTCA & 4.7 & 5.7 & 2.3 & 23.8 & 64 & 3.9 & 5.1 & 2.0 & 24.4 & 38 \\
\hline DTAA & 0.4 & 0.5 & 0.2 & 2.0 & 64 & 0.2 & 0.3 & 0.1 & 1.4 & 34 \\
\hline Total organic acids & 22.8 & 14.9 & 18.7 & 76.7 & 64 & 19.3 & 13.3 & 15.7 & 69.8 & 38 \\
\hline OS 154 & 6.6 & 6.0 & 4.5 & 25.7 & 63 & 5.3 & 4.6 & 4.3 & 24.6 & 38 \\
\hline OS 156 & 5.3 & 3.8 & 4.3 & 23.1 & 64 & 4.3 & 3.1 & 3.5 & 19.8 & 38 \\
\hline OS 170 & 3.5 & 2.3 & 2.7 & 10.3 & 63 & 3.1 & 2.0 & 2.5 & 11.5 & 37 \\
\hline OS 182 & 1.4 & 0.8 & 1.2 & 3.4 & 55 & 0.6 & 0.4 & 0.6 & 1.6 & 37 \\
\hline OS 200_1 & 7.1 & 6.7 & 4.4 & 33.1 & 64 & 4.5 & 3.9 & 3.0 & 22.2 & 37 \\
\hline OS 200_2 & 6.4 & 6.3 & 4.1 & 18.4 & 5 & 3.1 & 2.1 & 2.6 & 6.7 & 5 \\
\hline OS 208 & 5.0 & 3.3 & 5.7 & 14.2 & 63 & 4.1 & 0.8 & 4.1 & 5.6 & 38 \\
\hline OS 210 & 2.8 & 2.4 & 2.0 & 8.4 & 63 & 1.8 & 1.0 & 1.9 & 4.3 & 38 \\
\hline OS 212 & 7.4 & 6.0 & 5.0 & 32.2 & 64 & 6.2 & 4.7 & 4.6 & 27.8 & 38 \\
\hline OS 214 & 5.1 & 4.5 & 3.6 & 22.3 & 64 & 4.4 & 3.1 & 3.8 & 17.9 & 38 \\
\hline OS 216 & 5.0 & 6.8 & 2.8 & 36.9 & 60 & 3.2 & 3.3 & 2.4 & 20.8 & 34 \\
\hline OS 248 & 0.8 & 0.4 & 0.8 & 2.3 & 57 & 0.6 & 0.3 & 0.6 & 1.7 & 37 \\
\hline OS 250 & 2.3 & 1.1 & 2.1 & 6.8 & 64 & 2.4 & 2.1 & 1.9 & 12.4 & 38 \\
\hline OS 252 & 1.2 & 1.2 & 0.6 & 5.2 & 53 & 0.9 & 0.9 & 0.6 & 4.1 & 33 \\
\hline OS 254 & 1.3 & 1.5 & 0.8 & 7.9 & 63 & 1.1 & 1.2 & 0.8 & 7.4 & 38 \\
\hline OS 268 & 2.5 & 2.3 & 1.6 & 13.1 & 64 & 2.2 & 2.2 & 1.6 & 13.9 & 38 \\
\hline OS 280 & 2.6 & 2.5 & 1.8 & 11.5 & 60 & 2.2 & 2.0 & 1.6 & 10.3 & 38 \\
\hline OS 298 & 1.3 & 1.1 & 0.8 & 4.1 & 28 & 0.8 & 1.0 & 0.5 & 3.9 & 16 \\
\hline OS 334 & 0.6 & 0.3 & 0.6 & 1.0 & 8 & 0.8 & - & 0.8 & 0.8 & 1 \\
\hline Total organosulfates & 59.8 & 44.5 & 43.8 & 130.6 & 64 & 46.9 & 31.1 & 36.3 & 144.0 & 38 \\
\hline NOS 295 & 0.5 & 0.6 & 0.3 & 4.2 & 46 & 0.4 & 0.3 & 0.4 & 1.2 & 15 \\
\hline NOS 297 & 1.4 & 0.7 & 1.3 & 3.7 & 64 & 0.9 & 0.6 & 0.7 & 3.4 & 38 \\
\hline NOS 311 & 0.9 & 0.8 & 0.4 & 2.4 & 7 & 0.5 & 0.5 & 0.4 & 1.8 & 8 \\
\hline NOS 313 & 0.7 & 0.7 & 0.5 & 3.4 & 56 & 0.6 & 0.6 & 0.5 & 3.0 & 30 \\
\hline NOS 327 & 0.9 & 0.7 & 0.7 & 3.6 & 48 & 0.6 & 0.6 & 0.5 & 2.8 & 29 \\
\hline NOS 329 & 0.8 & 0.9 & 0.4 & 3.6 & 19 & 0.5 & 0.6 & 0.3 & 2.6 & 17 \\
\hline NOS 331 & 0.3 & 0.2 & 0.2 & 1.2 & 41 & 0.3 & 0.3 & 0.2 & 1.5 & 26 \\
\hline NOS 340 & 0.2 & 0.1 & 0.2 & 0.2 & 3 & - & - & - & - & - \\
\hline NOS 343 & 0.8 & 0.4 & 0.8 & 1.4 & 24 & 0.4 & 0.4 & 0.4 & 1.0 & 4 \\
\hline Total nitrooxy organosulfates & 3.9 & 1.3 & 2.8 & 3.7 & 64 & 2.8 & 1.2 & 2.1 & 1.8 & 36 \\
\hline
\end{tabular}

\subsection{Inter-site, day/night variability and inter-species correlation}

The non-parametric $U$ Mann-Whitney test was performed on the data sets to analyze the inter-site variability between
HCAB and Ris $\varnothing$ during the overlapping period (19 May1 June and 17-22 June) where data from both sites were available. The $90 \%$ confidence interval was used for evaluation of the statistical significance to account for the possible field sampling, filter extraction and quantification 
uncertainties. The test results showed that 14 parameters out of the 41 tested parameters were statistically different between the two sites at the $90 \%$ confidence interval $(p<0.1)$ (Supplement Table S4). These 14 parameters included 6 organic acids (benzoic acid, pimelic acid, phthalic acid, suberic acid, pinonic acid, and azelaic acid), the concentrations of total first-generation organic acids, 5 organosulfates (OS 182, OS 200, OS 210, OS 248 and OS 298), 1 nitrooxy organosulfate (NOS 297) and the concentration of total nitrooxy organosulfates. The species with statistically higher concentrations were mostly from HCAB (12 out of 14), with the exception of benzoic acid and pinonic acid, which showed significantly higher concentrations at Ris $\varnothing$. While a higher occurrence of benzoic acid at the semi-rural background site Ris $\varnothing$ was unexpected, it seems that the urban curbside site $\mathrm{HCAB}$ was associated with enhanced concentrations of both biogenic (suberic acid and azelaic acid) and anthropogenic (pimelic acid and phthalic acid) compounds in addition to the anthropogenic-biogenic coupling species (OS 182, OS 200, OS 210, OS 248, OS 298 and NOS 297), which probably indicated some local anthropogenic enhancement impacts on the concentration levels of the compounds. In fact, the total concentrations of organic acids and nitrooxy organosulfates were also found at significantly higher concentrations at $\mathrm{HCAB}$. In contrast, the second-generation product of pinonic acid, MBTCA, which has been regarded as an indicator of photochemical aging of pinonic acid by $\mathrm{OH}$ (Müller et al., 2012) was not statistically different between the two sites. The fact of a statistically higher concentration level of the pinonic acid precursor at Ris $\varnothing$ and the indifferent concentration of its product MBTCA at the sites probably suggest that the degree of photochemical aging was not directly governed by the concentrations of the precursor at the semi-rural background site Risø.

The variability between daytime and nighttime samples at each site during the whole field study was also analyzed using a non-parametric $U$ Mann-Whitney test at the $90 \%$ confidence interval. The test results showed statistically indistinguishable daytime and nighttime concentrations for most species (Supplement Tables S1-2), with the exception of higher daytime concentrations of phthalic acid ( $p=0.0385)$, OS $210(p=0.0622)$ and NOS $343(p=0.0825)$ at HCAB and higher nighttime concentrations of NOS 297 at both sites $(p=0.0011)$. Phthalic acid, OS 210 and NOS 297 were associated with high numbers of valid measured daytime or nighttime concentrations $(N \geq 30)$, whereas NOS 343 was associated with a lower number of valid $N\left(N_{\text {day }}=10\right.$; $N_{\text {night }}=13$ ).

Phthalic acid is widely used in plasticizer substrates and could be primarily emitted to the atmosphere from offgassing of plasticizers from plastics (Fraser et al., 2003), though previous studies have also suggested that it correlated with SOA in ambient samples (Fraser et al., 2003; Fine et al., 2004; Schauer et al., 2002). A recent study of the photooxidation of naphthalene has also indicated the link between phthalic acid formation and photochemistry, while pointing towards negligible primary emissions of the compound based on laboratory and field measurements (Kleindienst et al., 2012). The findings support our observation of higher daytime concentration of phthalic acid at HCAB, though phthalic acid was not necessarily formed directly at the site. Meanwhile the indifferent daytime and nighttime concentrations of phthalic acid at Ris $\varnothing$ were probably governed by a generally lower concentration level of the species at the site (Supplement Table S4). The other compound with significantly higher daytime concentrations at HCAB was OS 210, which has recently been reported in aerosols in the Arctic (Hansen et al., 2014).

The compound NOS 297 ( $m / z$ fragments 296, 233, 177, 163 and 97 ) showed significantly higher nighttime concentration at both sites, though its concentrations were statistically higher at HCAB compared to Ris $\varnothing$ (Supplement Table S4). This species was previously detected in ambient aerosols (Gao et al., 2006; Reemtsma et al., 2006; Kristensen and Glasius, 2011) and has been suggested as an oxidation product of limonene-like monoterpene precursors (Surratt et al., 2008b). In this study, NOS 297 was identified as the major nitrooxy organosulfate (Table 4), accounting for 36 and $34 \%$ of the total concentrations of nitrooxy organosulfates detected at HCAB and Ris $\varnothing$, respectively. The higher nighttime occurrence of NOS 297 could indicate the impacts of local or regional nighttime chemistry on the concentration level of the compound. In fact, it has been suggested that the formation of nitrooxy organosulfates involves nighttime nitrate $\left(\mathrm{NO}_{3}\right)$ radical chemistry (Iinuma et al., 2007a, b; Surratt et al., 2008b). In contrast, NOS 343 showed significantly higher daytime concentrations at $\mathrm{HCAB}$, though the statistical calculation was associated with a lower number of measurements, as mentioned above. Too few measurements of NOS 343 were available at Ris $\varnothing$ to compare its daytime and nighttime concentrations. Overall, significantly higher nighttime concentrations were observed for total nitrooxy organosulfates at both sites (Supplement Tables S1-2), which was attributed to the predominant contribution from the nighttimedominant species NOS 297. As a majority of the detected species did not show any immediate evidence of local site impacts on their concentration levels according to the $U$ MannWhitney test results, the relations among the compounds were furthermore investigated using $R^{2}$ correlation coefficients to unveil any potential driving mechanisms or factors influencing their formation. The correlation coefficients were calculated for each pair of species at each site and subsequently averaged for both sites. The averaged $R^{2}$ correlation coefficients are presented in Fig. 2, with each organic acid, organosulfate and nitrooxy organosulfate compound (lines) correlating with other species ( $x$ axis). Relative standard deviations (RSD, \%) for the corresponding averaged $R^{2}$ correlation coefficient are shown in Supplementary Table 1. Only 36 out of the total 38 species were used to calculate the $R^{2}$ correlation coefficient values, as those with very few 


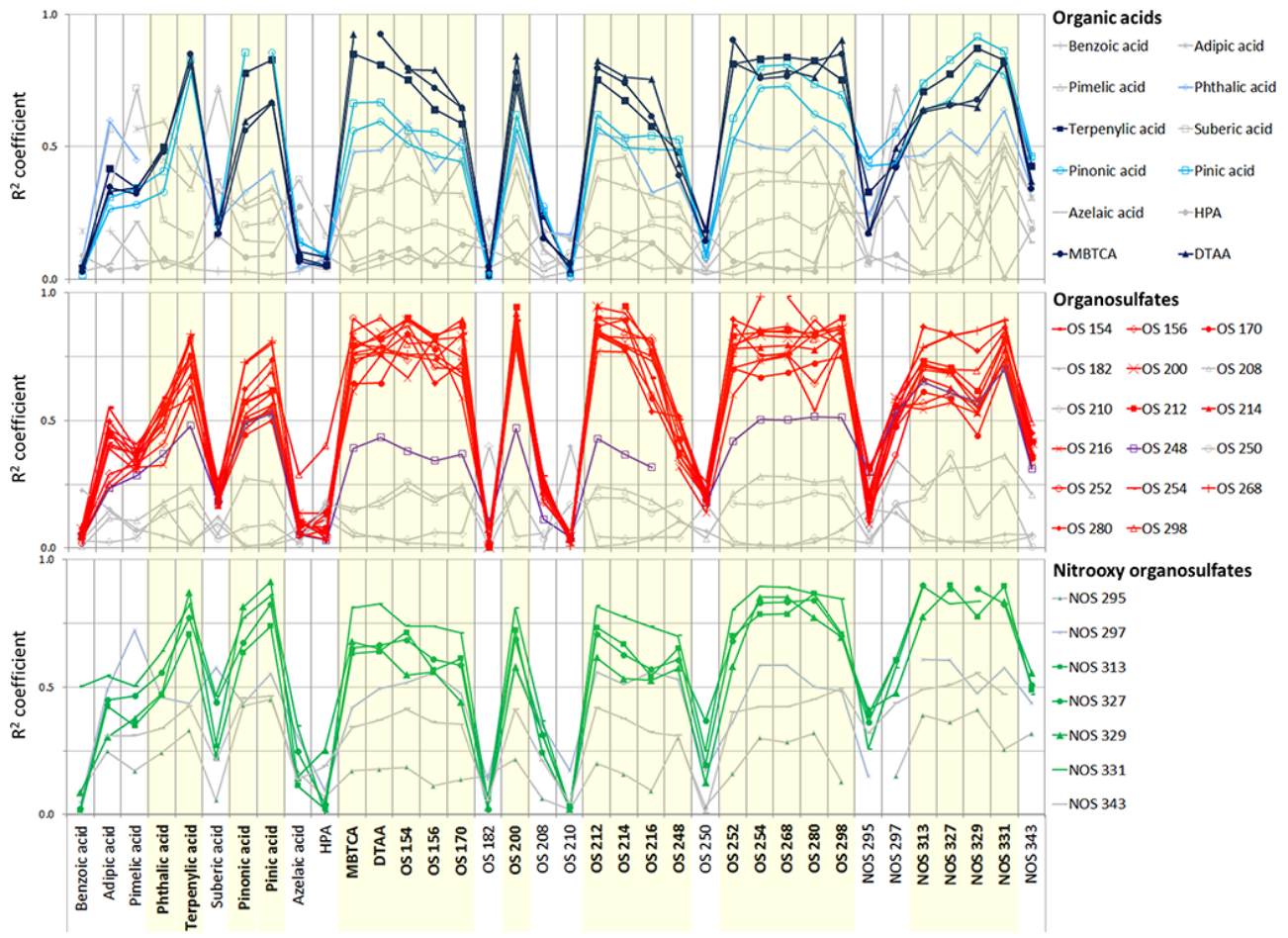

Figure 2. Correlations between organic acids, organosulfates and nitrooxy organosulfates with other detected species in each sample throughout the sampling period (excluding those with too few measurements), expressed as correlation coefficient $\left(R^{2}\right)$. The results show $R^{2}$ coefficient averaged from the two sites. High $R^{2}$ values $(>0.5)$ were found among a specific group of species (yellow shade), suggesting common sources. A few other species, including pinonic acid, pinic acid, phthalic acid, and OS 248 also partly followed the correlation pattern.

measurement values were excluded. The results in Fig. 2 were divided into panels of organic acids (top), organosulfates (middle) and nitrooxy organosulfates (bottom).

Figure 2 shows a clear correlating group with high $R^{2}$ correlation coefficient values $(>0.5)$ among the species in the group, which is comprised of certain organic acids, organosulfates and nitrooxy organosulfates. The correlating group included 3 organic acids, namely terpenylic acid, MBTCA and DTAA (dark blue), a vast number of 12 organosulfates (red) and 4 nitrooxy organosulfates (green). These organosulfates and nitrooxy organosulfates, among others, included species closely related in molecular weight, such as the groups of OS $(154,156)$, OS $(212,214,216)$, OS $(252,254)$ and NOS $(327,329,331)$. The organic acids pinonic and pinic acid (light blue) and OS 248 (purple) seemed to only partly follow the correlation pattern as the degree of correlation was somewhat lower, especially with regards to the correlation between these species and organosulfates.

The degree of correlation (calculated as the $R^{2}$ values) among the mentioned specific compounds was persistent at both study sites, as evident by the generally lower deviation with small RSD values (\%) associated with averaging the $\mathrm{R}$-squared values from both sites as opposed to the uncorrelated species (Supplement Table S3). The organosulfates correlated consistently well with the organic acids and the other organosulfates within the correlating group, with RSD ranging from typically a few to over $20 \%$ between sites. Correlation coefficients between the nitrooxy organosulfates and the other species showed larger discrepancies between the two sites, with RSD ranging from a few percent (NOS 313) to considerably higher percentages (NOS 327, 329 and 331), mostly due to a higher correlation level of these species at Ris $\emptyset$ compared to HCAB. Concentrations of pinonic acid, pinic acid and phthalic acid, which only partly followed the correlation pattern, showed larger deviations between the two sites. In contrast, OS 248 , which also partly followed the pattern (with slightly lower $R^{2}$ coefficient $\sim 0.5$ ), showed a highly consistent correlating tendency at both sites with low RSD values. The consistent correlation pattern among the group of organic acids, organosulfates and nitrooxy organosulfates of different precursors detected at both sites probably indicate a common source for the species at both sites.

\subsection{Regional impacts}

Figure 3 shows the temporal variation of the total concentrations of organic acids, organosulfates, nitrooxy organosulfates and $\mathrm{PM}_{1}$ detected at $\mathrm{HCAB}$ and Ris $\varnothing$ during the field study. It is apparent that all classes of compounds showed 
similar temporal patterns, and the two sites do not differ substantially, which were attributed to the large contribution of compounds belonging to the correlating group affecting both sites. The observations strongly indicated that the major sources or chemistry governing the total concentration levels of the compounds must occur at a spatial location affecting both the urban curbside and semi-rural background sites, which represent quite different environments (Fig. 1). Elevated total concentrations of organic acids, organosulfates and nitrooxy organosulfates seemed to occur at both sites during the same daytime or nighttime interval, exemplified by the daytime samples on 22 May, 31 May and 18 June or the nighttime sample on 23 May. Several other concentration maxima occurring on 6 June (daytime) and 8 June (nighttime) were observed at HCAB (data from Ris $\varnothing$ were unavailable for these days). Organosulfate 200_2 (from MBO), which was mostly found at levels below the detection limit, was detected in considerably higher concentrations during these episodes of concentration maxima (for example in 31 May, 18 June (daytime) and 23 May (nighttime) samples).

The correlation between the total concentration level of organosulfates and the concentration of $\mathrm{SO}_{4}^{2-}$ ion measured by IC was also examined. A relatively high correlation coefficient value $\left(R^{2}=0.6\right)$ was obtained between the total organosulfates and sulfate at the HCAB site with the episodes of highest concentrations of organosulfates coinciding with peak concentrations of the $\mathrm{SO}_{4}^{2-}$ ion (Fig. 3), which is in line with previous observations of aged continental aerosols over the southeast Pacific Ocean (Hawkins et al., 2010). The correlation between organosulfates and inorganic sulfate also agrees with previously proposed formation mechanisms for organosulfates, including the reactive uptake of epoxides on the surface of acidic sulfate aerosols (Iinuma et al., 2009; Minerath and Elrod, 2009; Surratt et al., 2010; Lin et al., 2013; Worton et al., 2013) and sulfate radical-initiated formation in the bulk phase (Nozière et al., 2010). However, while this observation may support related formation processes of the organosulfates and the sulfate ion, the resemblance in concentration trend among sulfate, organosulfates, organic acids, and nitrooxy organosulfates may also indicate that organic acids, organosulfates and nitrooxy organosulfates could also partition into existing sulfate aerosol. It should be noted that the correlation was only visible at the urban curbside site HCAB, while such correlation was not found at $\operatorname{Ris} \varnothing\left(R^{2}=0.3\right)$.

In general, the production rate of $\mathrm{NO}_{3}$ radical was one order of magnitude higher at the urban site HCAB compared to the semi-rural background Ris $\varnothing$, which was also observed in an earlier study in the region and attributed to higher emissions of $\mathrm{NO}_{2}$ in urban condition (Ljungstrom and Hallquist, 1996). Although the formation of nitrooxy organosulfates could involve nighttime $\mathrm{NO}_{3}$ radical chemistry as discussed above, no direct correlation was found between the nighttime total concentration level of nitrooxy organosulfates and the corresponding production rate of $\mathrm{NO}_{3}$ radical at $\mathrm{HCAB}\left(R^{2}=0.1\right)$. Meanwhile, a good correlation $\left(R^{2}=0.6\right)$ of nighttime $P_{\mathrm{NO}_{3}}$ and nighttime total concentration of nitrooxy organosulfates was found at Ris $\varnothing$ (Fig. 3). The difference could be attributed to the continuous emissions of NO from automobiles in the city center, which reacts with $\mathrm{NO}_{3}$ radical and complicates the observed trend of its production rate.

$\mathrm{NO}_{3}+\mathrm{NO} \rightarrow 2 \mathrm{NO}_{2}$

In addition, the observed concentrations of nitrooxy organosulfates could also be affected by both local and longrange transported impacts. The extent and impact of longrange transport, the impact of the interplay between $\mathrm{O}_{3}, \mathrm{NO}_{2}$ and the production rate of $\mathrm{NO}_{3}$ radical on the possible local species will be discussed in more detail below.

In order to investigate the regional impacts on the concentration levels of the detected compounds, 5-day air mass back trajectories were calculated using the HYSPLIT model for every $12 \mathrm{~h}$ sample (Draxier and Hess, 1998). As HCAB and Ris $\varnothing$ are relatively close with a distance of $\sim 30 \mathrm{~km}$ between them, HYSPLIT calculations were only performed for the HCAB site. The results revealed a dominating westerly origin of air masses during most of the campaign period. However, a clear dominance of the southeasterly air masses was found to be associated with the daytime or nighttime episodes of elevated concentrations, including the daytime samples on 22, 26 and 31 May and 6 and 18 June and the nighttime sample on 8 June. The traveling path of the southeasterly air masses probably involved the region around the borders between Germany, Poland and Czech Republic (Figs. 1, 4). It must be noted that the air masses following the southeasterly direction could have different origins (35 days backwards) but all passed the southeasterly region 12 days immediately before arrival at the sampling site. An example of the impacts of air masses arriving from the southeasterly direction is shown for 3 consecutive days on 30 May (nighttime), 31 May (daytime with elevated concentrations) and 1 June (daytime) where data from both $\mathrm{HCAB}$ and Ris $\varnothing$ were available (Fig. 4). To support the interpretation of the HYSPLIT calculations, emissions of isoprene and monoterpenes (daily) calculated using the MEGAN model and $\mathrm{SO}_{2}$ (monthly) calculated using the DEHM model, are also shown in Fig. 4 to illustrate the magnitude of biogenic and anthropogenic emissions in the region.

Figure 4 shows a sudden change of air mass origin from westerly (30 May) to southeasterly (31 May) back to westerly (1 June), which was coupled with a major episode on 31 May with elevated concentrations of the organic acids, organosulfates and nitrooxy organosulfates (Fig. 3). The modeled isoprene and monoterpene daily emissions did not vary noticeably over the corresponding days. This indicated that VOC emissions were probably not the limiting factor in the formation of the investigated compounds. 


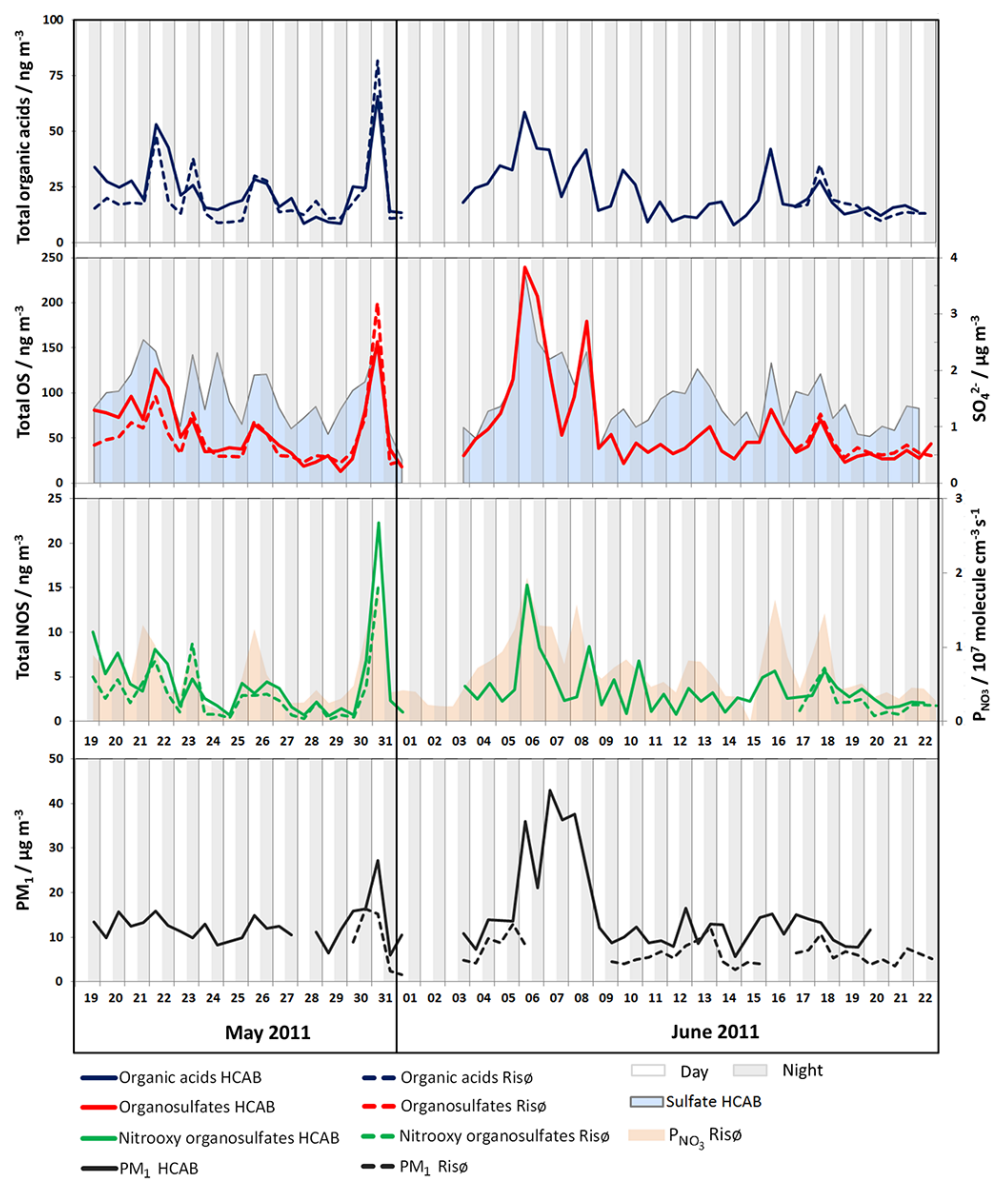

Figure 3. Temporal trends of total concentrations of organic acids, organosulfates, nitrooxy organosulfates and $\mathrm{PM}_{1}$ at the urban curbside site $\mathrm{HCAB}$ (solid line) and the semi-rural background site Ris $\emptyset$ (dashed line). The figure shows a strong correlation between the two sites and among the three categories of compounds examined. Sulfate (HCAB) and production rate of $\mathrm{NO}_{3}$ radical (Ris $\varnothing$ ) are also shown in the organosulfate and nitrooxy organosulfate panels, respectively.

Figure 4 also shows a map of average $\mathrm{SO}_{2}$ emissions over the 2 months of May-June 2011. Though the $\mathrm{SO}_{2}$ emission map could not be used to evaluate the daily change in anthropogenic emissions to further investigate the observed elevated concentrations on 31 May, it did, however indicate strong $\mathrm{SO}_{2}$ emissions from hotspots in the region that were passed over by the southeasterly air mass shown in the trajectories. This could probably influence the formation of the organosulfates and nitrooxy organosulfates during longrange transport to the sites. The accompanying organic acids, which were also found at high concentrations correlating to the organosulfates and nitrooxy organosulfates, could also be long-range transported to the sampling sites.

It is difficult to determine the exact spatial location of the major sources or chemistry governing the total concentrations of the compounds at the two sites, which is partly due to the coarse resolution of the $\mathrm{SO}_{2}$ emission map. However, it is unlikely that the major source location would be in the local proximity of the two sites due to the highly different local conditions between the urban curbside site HCAB and the semi-rural background site Ris $\varnothing$ (Fig. 1). Such a local source, if present, would be subject to immediate different local background conditions and also varying local wind conditions, while in contrast, a highly similar temporal variation pattern of total observed concentrations was found at the sites during the whole campaign period (Fig. 3). Furthermore, any possible point source located southeasterly from HCAB and Ris $\varnothing$, which could affect both sampling sites would unlikely be in Denmark, as both sites are located only 10-20 km from Baltic Sea in the southeasterly direction (Fig. 1). The source region is therefore possibly located at the broader regional scale across the Baltic Sea extending to the southerly neighboring countries.

Particle mass concentrations were calculated based on integration of the calculated particle mass size distributions (from DMPS data), which were further based on measured particle number size distributions assuming particle sphericity, using a SOA particle density of $1.7 \mathrm{~g} \mathrm{~cm}^{-3}$ (Stock et al., 2011) (Fig. 3). This density value is close to the bulk densities of ammonium sulfate and nitrate, which are expected 


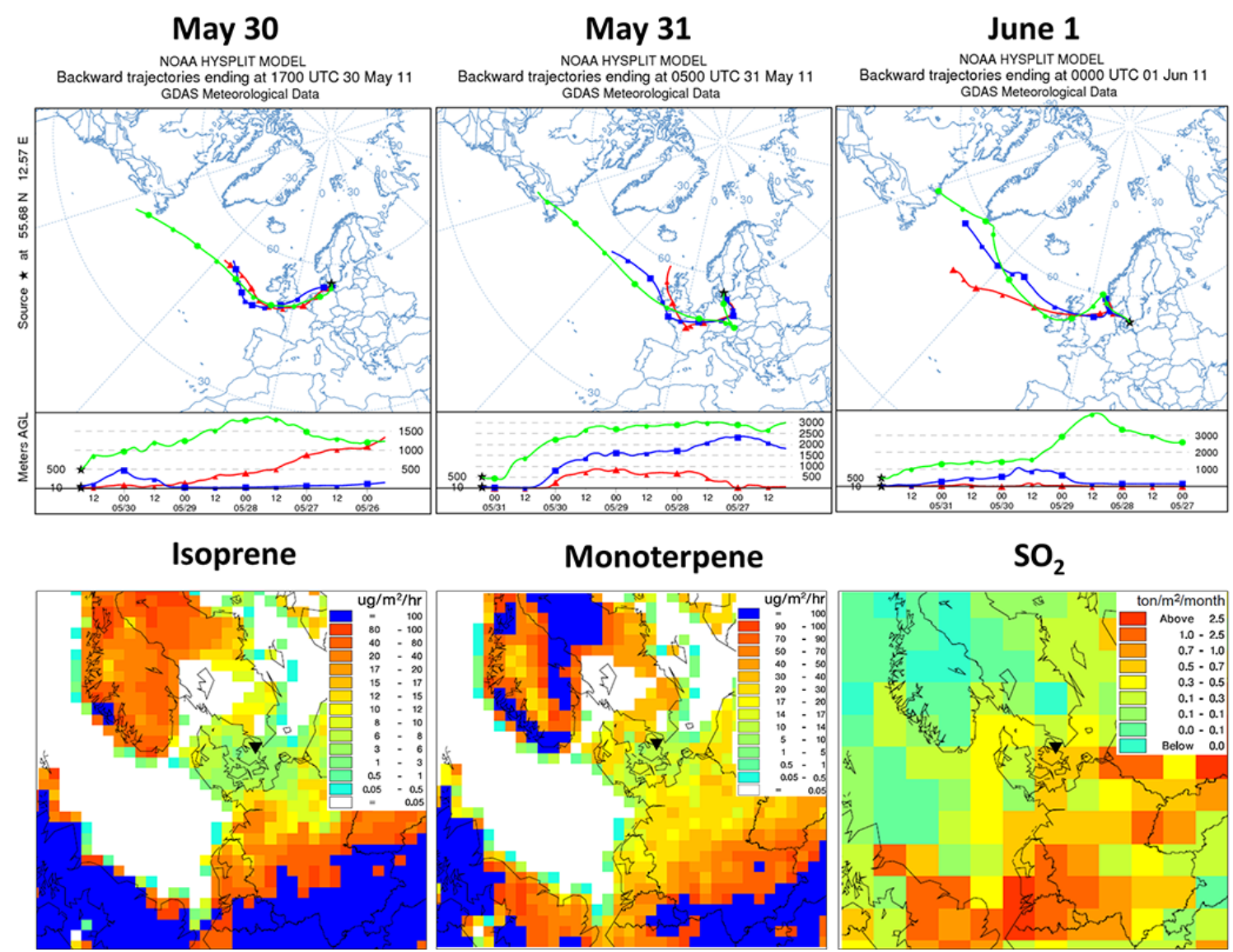

Figure 4. A sudden change in air mass back trajectories on 31 May to southeasterly direction was coupled with elevated concentrations of organosulfates, nitrooxy organosulfates, and organic acids at both HCAB and Ris $\varnothing$. Modeled daily isoprene and monoterpene emissions did not vary significantly over the 3 days. The $\mathrm{SO}_{2}$ emission map (May-June average) showed a higher abundance of emission hotspots in the southeasterly direction (observed on 31 May) compared to the westerly direction (observed on 30 May and 1 June). HCAB is marked at the bottom tip of the black triangle.

to be the major components of aged accumulation mode particles. The detected and quantified organosulfates and nitrooxy organosulfates contributed to $0.1-1.0 \%$ (approximately $0.5 \%$ on average) of $\mathrm{PM}_{1}$ mass at $\mathrm{HCAB}$ and 0.4 $1.5 \%$ (approximately $0.8 \%$ on average) of $\mathrm{PM}_{1}$ mass at Ris $\varnothing$. The values are considerably lower than previous estimates, including $30 \%$ (Surratt et al., 2008b) or 5-10\% contribution of organosulfates to total organic mass (Tolocka and Turpin, 2012). $\mathrm{PM}_{1}$ concentrations at $\mathrm{HCAB}$ were in the lower range during the days under the influence of southeasterly air mass (22, 26, 31 May and 18 June (daytime), with the exception of June 6 (daytime). The period of high $\mathrm{PM}_{1}$ concentrations at HCAB (6-8 June) seemed to link to other local conditions, including episodes of elevated concentrations of $\mathrm{SO}_{2}$ and $\mathrm{NO}_{\mathrm{x}}$ (Fig. 5 and Supplement Fig. 1). The local impacts are discussed further in the section below.

\subsection{Local impacts}

The possible local anthropogenic impacts were investigated by examining the species of significantly higher concentrations at $\mathrm{HCAB}$, which did not belong to the correlating group, including OS $182(\mathrm{~m} / \mathrm{z}$ fragments 181,97$)$, OS 210 $(\mathrm{m} / \mathrm{z}$ fragments 209, 153, 137, 97 and 79) and NOS $297(\mathrm{~m} / \mathrm{z}$ fragments 233, 177, 163 and 97). As displayed in Fig. 5, the patterns of changes in OS 182 and OS 210 concentrations in May were considerably similar, with a few episodes of high daytime concentrations, especially during the period 20-25 May with a lower concentration on 22 May (daytime). Such observations stand in contrast to the trend of the total organosulfate concentrations during the same period, where a generally lower concentration level was observed except from elevated daytime concentrations on 22 May (Fig. 3). Assuming that the trend of variations for the total detected species in Fig. 3 was mostly governed by long-range transported compounds belonging to the highly correlated group, the trend of OS 182 and OS 210, which did not belong to the 


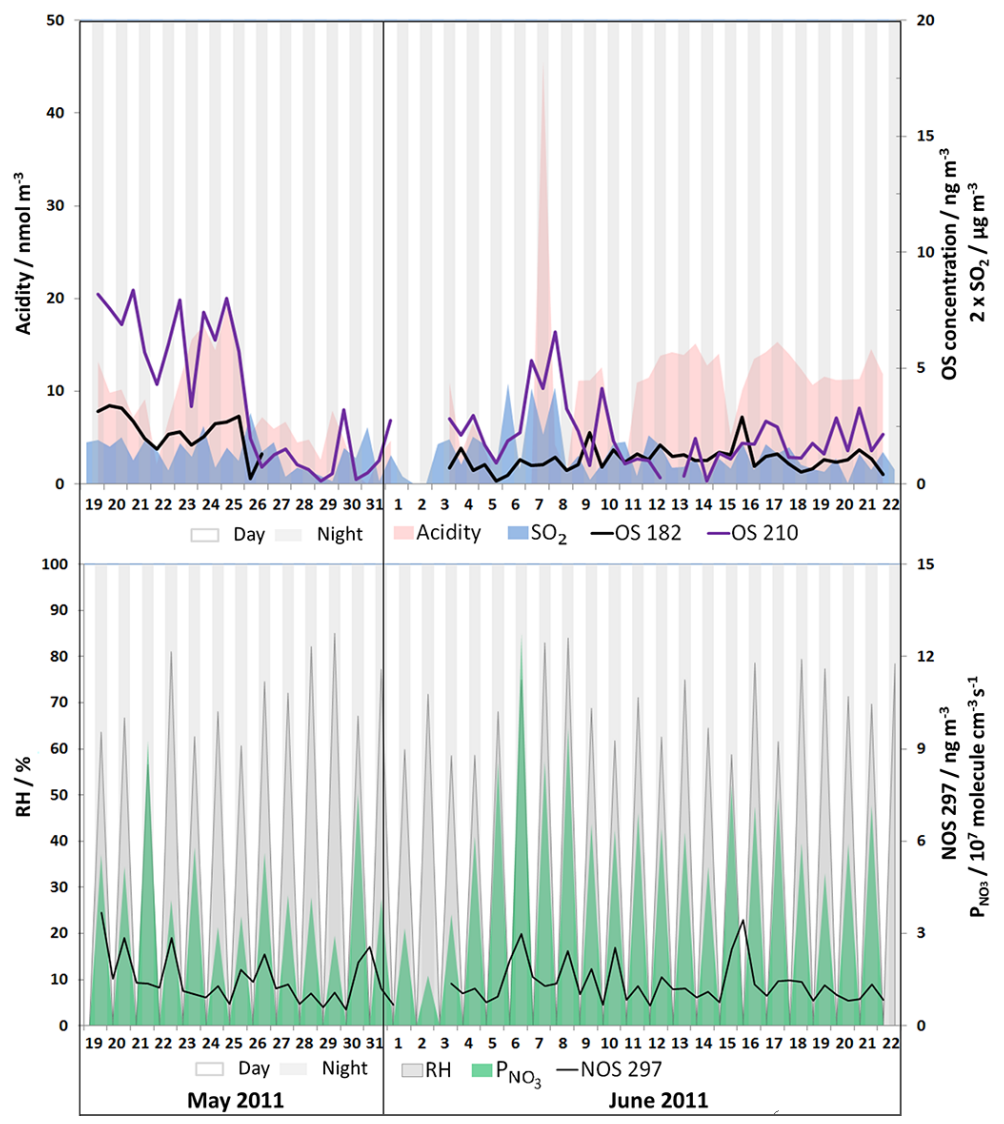

Figure 5. Time profiles of selected species of significantly higher concentration levels at HCAB, including OS 182 , OS 210 and NOS 297. Concentrations of OS 182 and OS 210 are shown against level of $\mathrm{SO}_{2}$ and acidity at $\mathrm{HCAB}$, while concentration trend of NOS 297 is shown against nighttime production rate of $\mathrm{NO}_{3}$ radical and nighttime relative humidity at $\mathrm{HCAB}$.

correlated group, could probably reflect some local impact on the concentration levels of these species. However, while OS 182 and OS 210 seemed to correlate well in May, concentrations of the species deviated towards the end of the field study (Fig. 5), which could be partly attributed to additional input from long-range transport to the site. For example, elevated daytime concentration of OS 182 was observed on 16 June, which is one of the characteristic days of southeasterly arriving air masses associated with higher total concentrations of the detected species (Fig. 3).

Local impacts were studied to explain the significantly higher concentrations of OS 182, OS 210 and NOS 297 at the urban curbside site HCAB. Temporal variation of gases $\left(\mathrm{NO}, \mathrm{NO}_{\mathrm{x}}\right.$ and $\mathrm{SO}_{2}$ ), aerosol acidity level (calculated from charge balance using $\left[\mathrm{SO}_{4}^{2-}\right],\left[\mathrm{NO}_{3}^{-}\right]$, and $\left[\mathrm{NH}_{4}^{+}\right]$following Zhang et al. (2012b)) at HCAB (Fig. 5), as well as meteorological conditions including RH (Fig. 5), temperature (Temp) and global radiation (GR) (Supplement Fig. S1) at the urban background site HCOE (located in close proximity to $\mathrm{HCAB}$ ) were analyzed. As can be seen from Fig. 5, the period 20-25 May was accompanied by a generally higher level of aerosol acidity, which decreased on 22 May (daytime).
Such variation of the aerosol acidity level perfectly matched the trend of the varying concentrations of OS 210 and OS 182 during the same period (Fig. 5). In fact, the aerosol acidity level has been suggested as an essential parameter in the formation of organosulfates (Zhang et al., 2012b). At the same time, the concentration level of the organosulfates might rather be affected by an inter-play between the aerosol acidity level and other factors, such as the global radiation and temperature. For example the 20 and 21 May (daytime) samples showed high concentrations of OS 182 and OS 210, which were comparable to the concentrations on 24 or 25 May (daytime) samples (Fig. 5), whereas the aerosol acidity level on 20 or 21 May was considerably lower (daytime) compared to the other days (Fig. 5). This time frame was, however, accompanied with a higher level of global radiation, especially on 21 May $\left(579 \mathrm{~W} \mathrm{~m}^{-2}\right)$ compared to later days 24 25 May (daytime) (Supplement Fig. 1). While a higher level of global radiation could probably enhance the oxidation of $\mathrm{SO}_{2}$ by the $\mathrm{OH}$ radical and thereby result in higher concentrations of $\mathrm{SO}_{4}^{2-}$ as observed with the 20-21 May (daytime) samples, $\mathrm{NH}_{4}^{+}$was also detected at higher concentrations with these samples, resulting in an overall lower aerosol 
acidity, calculated based on ion charge balance on the days. In addition, the higher temperature observed on 20-21 May compared to 24-25 May may also have contributed to enhance the formation of supposed local organosulfates in the earlier samples, by means of enhancing biogenic VOC emissions, or photochemistry in general. In fact, a considerably higher level of $\mathrm{O}_{3}$ oxidant was also found during the earlier days (20-21 May) compared to the later days (24-25 May), which would positively enhance the formation of SOA.

Higher daytime concentrations of OS 210 were also observed on 7 and 8 May, whereas the aerosol acidity reached its highest level of $46 \mathrm{nmol} \mathrm{m}^{-3}$ on 7 June (nighttime), interestingly with almost neutral conditions on the adjacent 7 June (daytime) and 8 June (daytime) (Fig. 5). At the same time, during these two daytime intervals, higher average concentrations of $\mathrm{SO}_{2}$ were also observed. At the same time, concentrations of $\mathrm{NO}$ and $\mathrm{NO}_{\mathrm{x}}$ in higher resolution $(30 \mathrm{~min})$ were also considerably elevated (Supplement Fig. 1). Meanwhile, the $\mathrm{O}_{3}$ level was in the lowest concentration range, presumably due to the lower level of sunlight in addition to titration by $\mathrm{NO}_{\mathrm{x}}$ (figure not shown). A close examination revealed that the $\mathrm{NO}$ and $\mathrm{NO}_{\mathrm{x}}$ were highest during the early morning and late afternoon hours, which are attributed to traffic emissions, though during the day course both NO and $\mathrm{NO}_{\mathrm{x}}$ remained at a higher level compared to the other days during the campaign period. This observation could be partially attributed to lower wind speed during the daytime on 7 June $\left(2.0 \mathrm{~m} \mathrm{~s}^{-1}\right)$ and on 8 June $\left(2.9 \mathrm{~m} \mathrm{~s}^{-1}\right)$, which was considerably lower than the average wind speed of $4.1 \mathrm{~m} \mathrm{~s}^{-1}$ for the whole campaign period. It must also be noted that this period was coupled with the highest $\mathrm{RH}$ range during the campaign period (Supplement Fig. S2), which resulted from the corresponding very low global radiation during the days. The observations indicated an inter-play between the anthropogenic gases, especially $\mathrm{NO}, \mathrm{NO}_{\mathrm{x}}$ and probably aqueous aerosol chemistry, leading to the occurrence of higher concentrations of OS 210 in these samples. A previous study by Dommen et al. (2006) on the effect of $\mathrm{RH}$ under high $\mathrm{NO}_{\mathrm{x}}$ conditions indicated that more volatile SOA were observed at higher RH rather than at lower RH. Additionally, SOA formation, including carboxylic acids and organosulfur compounds in cloud and fog droplets, have been hypothesized as plausible by Blando and Turpin (2000), while a recent smog chamber study by Zhang et al. (2012a) suggested that elevated RH values could mediate the formation of organosulfates, thereby emphasizing the role of wet sulfate aerosols in forming organosulfates in ambient aerosols. At the same time, though aerosol acidity has been found to enhance isoprene SOA formation under low initial NO conditions (Surratt et al., 2007c, 2010; Jaoui et al., 2010), seed aerosol acidity showed a negligible effect on SOA formation from isoprene under high initial NO conditions (Surratt et al., 2006), which implied the less important role of seed aerosol acidity on the formation of OS 210 on 7 and 8 June (daytime) where both $\mathrm{NO}$ and $\mathrm{RH}$ were high.
Further investigation of the meteorological conditions during the period where data from both sites were available (19 May-1 June and 17-22 June, see Supplement Fig. S2) revealed a possible coupling between higher temperature and global radiation $\left(508 \mathrm{Wm}^{-2}\right)$ with the occurrence of concentration maxima observed on days with the highest temperature 31 May (daytime) and 6 June (daytime) (Fig. 3). However, information was lacking on the spatial scale of high temperature and global radiation episodes to fully justify if concentration maxima were enhanced by high temperature and global radiation at source or at the sampling sites.

The third species used to study the local impacts was NOS 297, which showed significantly higher nighttime concentration as discussed above. A recent work by Rollins et al. (2013) has also suggested a correlation between nitrooxy organosulfates, including NOS 297 and total particulate organic nitrate $\left(\mathrm{RONO}_{2}\right)$, which results from oxidation of organic compounds in high $\mathrm{NO}_{\mathrm{x}}$ environment and $\mathrm{NO}_{3}$ radical chemistry. Although some possible long-range transport contribution to the observed concentration of NOS 297 at HCAB could not be completely eliminated, as shown by its elevated concentration seen during peak concentration days 31 May and 16 June, elevated concentrations of NOS 297 were observed predominantly at nighttime on 19, 20, 22, 26 May and 6, 8 and 10 June. To examine the local impacts on NOS 297, only the nighttime production rate of $\mathrm{NO}_{3}$ radical and nighttime RH are shown (Fig. 5). The RH condition during the nights of high concentrations of NOS 297 covered both the lower RH range (19, 20 May and 10 June) and the higher RH range (22 May, 6 and 8 June) of the whole campaign. A very high production rate of $\mathrm{NO}_{3}$ radical (12.8 and $9.7 \times 10^{7}$ molecule $\mathrm{cm}^{-3} \mathrm{~s}^{-1}$, respectively) was observed during the nights of the highest RH, June 6 and 8 , whereas during the in-between night 7 June, when RH was still in the high range, lower $P_{\mathrm{NO}_{3}}$ was observed, which was coupled with a considerably lower concentration of NOS 297. In contrast, lower $P_{\mathrm{NO}_{3}}$ was also observed during other nights of higher NOS 297 concentrations with lower RH condition (19, 20 May and 10 June). However, a lower RH range could also reduce the available condensation sink for particle precursors and thus facilitate the formation of NOS 297 by nighttime $\mathrm{NO}_{3}$ radical chemistry. It is thus unlikely if any single parameter such as RH or $P_{\mathrm{NO}_{3}}$ could be a prerequisite for the occurrence of elevated concentration of NOS 297 in this study. In addition, investigation of air mass back trajectories using HYSPLIT also revealed that the 22, 26 May and 6 June nighttime were affected by air masses arriving from the south-southeasterly direction, whereas on 8 June air masses arrived from the easterly direction. Such observations suggest that the detected nighttime concentrations of NOS 297 could be governed by both the local formation and the degree of long-range transport of the compound to the site. As a result, no direct correlation between nighttime concentrations of NOS 297 and $P_{\mathrm{NO}_{3}}$ was observed $\left(R^{2}=0.2\right)$. On the other hand, it should be noted that during this period 
of the year, the duration of the night is relatively short in Denmark, therefore calculation of nighttime concentrations would couple with higher uncertainty. Nevertheless, it seems probable that the occurrence of NOS 297 was favored by nighttime chemistry, regardless of whether the species were formed in situ or long-range transported to the site.

Local new particle formation (NPF) events were also examined using the DMPS data following Dal Maso et al. (2005) to investigate whether the local formation of organosulfates could be associated with particle nucleation at the sites. A limited number of NPF events were found to occur on the same days at the semi-rural background site Ris $\varnothing$, the urban background site HCOE and the urban curbside site $\mathrm{HCAB}$, though $\mathrm{HCAB}$ is heavily influenced by traffic emissions, resulting in generally short nucleation bursts rather than allowing a classic "banana" formation and growth. The NPFs, however, seemed to occur on the days with low concentrations of most organic acid, organosulfate and nitrooxy organosulfate species, including the possible local compounds OS 182 and OS 210, which agree with previous indications that NPF may occur more frequently in cleaner environments (Lyubovtseva et al., 2005; Kulmala et al., 2004b). As the occurrence of higher concentrations of the detected organic acids, organosulfates and nitrooxy organosulfates did not correspond to NPF events, which were coupled with the elevated occurrence of smaller-sized particles; it is likely that the organic acids, organosulfates and nitrooxy organosulfates belong to the accumulation mode. At the same time, any correlation to NPF should be investigated with size-segregated samples.

\section{Conclusion}

A field study was conducted from 19 May to 22 June 2011 at two sites in Denmark, including the urban curbside site HCAB and the semi-rural background site Ris $\varnothing$ to investigate the anthropogenic impacts on the formation of biogenic SOA via analysis of organosulfates and related oxidation products using HPLC-qTOF-MS. A substantial range of anthropogenic and biogenic organic acids, organosulfates and nitrooxy organosulfates were detected, identified and quantified. Isoprene oxidation products comprised a large fraction of the detected organosulfates, whereas a majority of the detected nitrooxy organosulfates may originate from limonene and/or monoterpenes. The $U$ Mann-Whitney statistical test showed significantly higher concentrations of specific biogenic and anthropogenic species at $\mathrm{HCAB}$, whereas an intraday statistical test only revealed significantly higher daytime concentrations of phthalic acid and OS 210 and significantly higher nighttime concentrations of NOS 297. Many detected compounds, including a group of organic acids, organosulfates and nitrooxy organosulfates of various precursors, were found belonging to a common highly correlated group, consistently affecting their concentration levels at both sites, suggesting a common source region or similarities in formation processes. The analysis of HYSPLIT back trajectories, together with isoprene and monoterpene emissions calculated by the MEGAN model and $\mathrm{SO}_{2}$ emissions based on the EMEP monitoring database, indicated that southeasterly air mass arriving from across the Baltic Sea could relate to the corresponding episodes of the elevated total concentrations at the sites, implying the importance of the regional impacts on the occurrence of the compounds.

The local impacts were also investigated for several selected species, which showed significantly higher concentrations at HCAB compared to Ris $\emptyset$ and did not belong to the correlating group, including OS 182, OS 210 and NOS 297. The results showed that the local factors, including aerosol acidity, RH, NO and probably some wet aerosol chemistry, could possibly lead to a higher occurrence of the organosulfates, whereas the major nitrooxy organosulfate NOS 297 could be favored by nighttime chemistry, in addition to temperature and global radiation, which could also enhance the concentrations of the long-range transported species at the sites. As only very few compounds were deemed as affected by the local conditions, the analysis of the local impacts was restricted to a modest number of compounds. In general, the regional impacts seemed to considerably exceed the local impacts. It was estimated that organosulfates and nitrooxy organosulfates contributed to approximately 0.5 and $0.8 \%$ of $\mathrm{PM}_{1}$ mass at $\mathrm{HCAB}$ and Ris $\varnothing$, respectively.

\section{The Supplement related to this article is available online at doi:10.5194/acp-14-8961-2014-supplement.}

Acknowledgements. This work was financially supported by the VILLUM foundation. We also thank R. Keller for providing the meteorological and gas data from The Danish Air Quality Monitoring Program.

Edited by: S. Brown

\section{References}

Aiken, A. C., Salcedo, D., Cubison, M. J., Huffman, J. A., DeCarlo, P. F., Ulbrich, I. M., Docherty, K. S., Sueper, D., Kimmel, J. R., Worsnop, D. R., Trimborn, A., Northway, M., Stone, E. A., Schauer, J. J., Volkamer, R. M., Fortner, E., de Foy, B., Wang, J., Laskin, A., Shutthanandan, V., Zheng, J., Zhang, R., Gaffney, J., Marley, N. A., Paredes-Miranda, G., Arnott, W. P., Molina, L. T., Sosa, G., and Jimenez, J. L.: Mexico City aerosol analysis during MILAGRO using high resolution aerosol mass spectrometry at the urban supersite (T0) - Part 1: Fine particle composition and organic source apportionment, Atmos. Chem. Phys., 9, 6633-6653, doi:10.5194/acp-9-6633-2009, 2009.

Blando, J. D., and Turpin, B. J.: Secondary organic aerosol formation in cloud and fog droplets: a literature evaluation of plau- 
sibility, Atmos. Environ., 34, 1623-1632, doi:10.1016/S13522310(99)00392-1, 2000.

Brandt, J., Silver, J. D., Frohn, L. M., Geels, C., Gross, A., Hansen, A. B., Hansen, K. M., Hedegaard, G. B., Skjoth, C. A., Villadsen, H., Zare, A., and Christensen, J. H.: An integrated model study for Europe and North America using the Danish Eulerian Hemispheric Model with focus on intercontinental transport of air pollution, Atmos. Environ., 53, 156-176, doi:10.1016/j.atmosenv.2012.01.011, 2012.

Calogirou, A., Larsen, B. R., and Kotzias, D.: Gas-phase terpene oxidation products: a review, Atmos. Environ., 33, 1423-1439, doi:10.1016/S1352-2310(98)00277-5, 1999.

Carlton, A. G., Pinder, R. W., Bhave, P. V., and Pouliot, G. A.: To What Extent Can Biogenic SOA be Controlled?, Environ. Sci. Technol., 44, 3376-3380, doi:10.1021/Es903506b, 2010.

Claeys, M., Iinuma, Y., Szmigielski, R., Surratt, J. D., Blockhuys, F., Van Alsenoy, C., Boge, O., Sierau, B., Gomez-Gonzalez, Y., Vermeylen, R., Van der Veken, P., Shahgholi, M., Chan, A. W. H., Herrmann, H., Seinfeld, J. H., and Maenhaut, W.: Terpenylic Acid and Related Compounds from the Oxidation of alpha-Pinene: Implications for New Particle Formation and Growth above Forests, Environ. Sci. Technol., 43, 6976-6982, doi:10.1021/Es9007596, 2009.

Dal Maso, M., Kulmala, M., Riipinen, I., Wagner, R., Hussein, T., Aalto, P. P., and Lehtinen, K. E. J.: Formation and growth of fresh atmospheric aerosols: eight years of aerosol size distribution data from SMEAR II, Hyytiala, Finland, Boreal Environ. Res., 10, 323-336, 2005.

De Gouw, J. and Jimenez, J. L.: Organic Aerosols in the Earth's Atmosphere, Environ. Sci. Technol., 43, 7614-7618, doi:10.1021/Es9006004, 2009.

DeMore, W. B., Sander, S. P., Golden, D. M., Hampson, R. F., Kurylo, M. J. Howard, C. J., Ravishankara, A. R., Kolb, C. E., and Molina, M. J.: Chemical Kinetics and Photochemical Data for use in Stratospheric Modeling, Evaluation No. 12, NASA Panel for Data Evaluation, Jet Propulsion Laboratory Publication 97-4, Pasadena, CA, January 15, http://jpldataeval.jpl.nasa. gov/pdf/Atmos97_Anotated.pdf (last access: 20 August 2014), 1997.

Dommen, J., Metzger, A., Duplissy, J., Kalberer, M., Alfarra, M. R., Gascho, A., Weingartner, E., Prevot, A. S. H., Verheggen, B., and Baltensperger, U.: Laboratory observation of oligomers in the aerosol from isoprene/ $\mathrm{NO}_{\mathrm{x}}$ photooxidation, Geophys. Res. Lett., 33, L13805, doi:10.1029/2006gl026523, 2006.

Donahue, N. M., Robinson, A. L., Stanier, C. O., and Pandis, S. N.: Coupled partitioning, dilution, and chemical aging of semivolatile organics, Environ. Sci. Technol., 40, 2635-2643, doi:10.1021/Es052297c, 2006.

Draxier, R. R. and Hess, G. D.: An overview of the HYSPLIT_4 modelling system for trajectories, dispersion and deposition, Aust. Meteorol. Mag., 47, 295-308, 1998.

Ellermann, T., Nøjgaard, J. K., Nordstrøm, C., Brandt, J., Christensen, J., Ketzel, M., and Jensen, S. S.: The Danish Air Quality Monitoring Programme. Annual Summary for 2011. , Scientific Report from DCE - Danish Centre for Environment and Energy No. 37, 63 pp. http://www2.dmu.dk/Pub/SR37.pdf (last access: 20 August 2014), 2012.

Fine, P. M., Chakrabarti, B., Krudysz, M., Schauer, J. J., and Sioutas, C.: Diurnal variations of individual organic compound constituents of ultrafine and accumulation mode particulate matter in the Los Angeles basin, Environ. Sci. Technol., 38, 12961304, doi:10.1021/Es0348389, 2004.

Fraser, M. P., Cass, G. R., and Simoneit, B. R. T.: Air quality model evaluation data for organics. 6. C-3-C-24 organic acids, Environ. Sci. Technol., 37, 446-453, doi:10.1021/Es0209262, 2003.

Fushimi, A., Wagai, R., Uchida, M., Hasegawa, S., Takahashi, K., Kondo, M., Hirabayashi, M., Morino, Y., Shibata, Y., Ohara, T., Kobayashi, S., and Tanabe, K.: Radiocarbon (C-14) Diurnal Variations in Fine Particles at Sites Downwind from Tokyo, Japan in Summer, Environ. Sci. Technol., 45, 6784-6792, doi:10.1021/Es201400p, 2011.

Galloway, M. M., Chhabra, P. S., Chan, A. W. H., Surratt, J. D., Flagan, R. C., Seinfeld, J. H., and Keutsch, F. N.: Glyoxal uptake on ammonium sulphate seed aerosol: reaction products and reversibility of uptake under dark and irradiated conditions, Atmos. Chem. Phys., 9, 3331-3345, doi:10.5194/acp-9-3331-2009, 2009.

Gao, S., Surratt, J. D., Knipping, E. M., Edgerton, E. S., Shahgholi, M., and Seinfeld, J. H.: Characterization of polar organic components in fine aerosols in the southeastern United States: Identity, origin, and evolution, J. Geophys. Res.-Atmos., 111, D14314, doi:10.1029/2005jd006601, 2006.

Glasius, M., Lahaniati, M., Calogirou, A., Di Bella, D., Jensen, N. R., Hjorth, J., Kotzias, D., and Larsen, B. R.: Carboxylic acids in secondary aerosols from oxidation of cyclic monoterpenes by ozone, Environ. Sci. Technol., 34, 1001-1010, doi:10.1021/Es990445r, 2000.

Goldstein, A. H. and Galbally, I. E.: Known and unexplored organic constituents in the Earth's atmosphere, Environ. Sci. Technol., 41, 1514-1521, 2007.

Gómez-González, Y., Surratt, J. D., Cuyckens, F., Szmigielski, R., Vermeylen, R., Jaoui, M., Lewandowski, M., Offenberg, J. H., Kleindienst, T. E., Edney, E. O., Blockhuys, F., Van Alsenoy, C., Maenhaut, W., and Claeys, M.: Characterization of organosulfates from the photooxidation of isoprene and unsaturated fatty acids in ambient aerosol using liquid chromatography/(-) electrospray ionization mass spectrometry, J. Mass Spectrom., 43, 371-382, doi:10.1002/Jms.1329, 2008.

Gómez-González, Y., Wang, W., Vermeylen, R., Chi, X., Neirynck, J., Janssens, I. A., Maenhaut, W., and Claeys, M.: Chemical characterisation of atmospheric aerosols during a 2007 summer field campaign at Brasschaat, Belgium: sources and source processes of biogenic secondary organic aerosol, Atmos. Chem. Phys., 12, 125-138, doi:10.5194/acp-12-125-2012, 2012.

Grell, G. A., Dudhia, J., and Stauffer, D. R.: A description of the fifth-generation Penn State/NCAR mesoscale model (MM5), NCAR/TN-398 STR, Penn State/NCAR, 1994.

Grosjean, D., Vancauwenberghe, K., Schmid, J. P., Kelley, P. E., and Pitts, J. N.: Identification of C3-C10 Aliphatic DicarboxylicAcids in Airborne Particulate Matter, Environ. Sci. Technol., 12, 313-317, doi:10.1021/Es60139a005, 1978.

Guenther, A., Karl, T., Harley, P., Wiedinmyer, C., Palmer, P. I., and Geron, C.: Estimates of global terrestrial isoprene emissions using MEGAN (Model of Emissions of Gases and Aerosols from Nature), Atmos. Chem. Phys., 6, 3181-3210, doi:10.5194/acp-63181-2006, 2006.

Hallquist, M., Wenger, J. C., Baltensperger, U., Rudich, Y., Simpson, D., Claeys, M., Dommen, J., Donahue, N. M., George, 
C., Goldstein, A. H., Hamilton, J. F., Herrmann, H., Hoffmann, T., Iinuma, Y., Jang, M., Jenkin, M. E., Jimenez, J. L., Kiendler-Scharr, A., Maenhaut, W., McFiggans, G., Mentel, Th. F., Monod, A., Prévôt, A. S. H., Seinfeld, J. H., Surratt, J. D., Szmigielski, R., and Wildt, J.: The formation, properties and impact of secondary organic aerosol: current and emerging issues, Atmos. Chem. Phys., 9, 5155-5236, doi:10.5194/acp-9-51552009, 2009.

Hansen, A. M. K., Kristensen, K., Nguyen, Q. T., Zare, A., Cozzi, F., Nøjgaard, J. K., Skov, H., Brandt, J., Christensen, J. H., Ström, J., Tunved, P., Krejci, R., and Glasius, M.: Organosulfates and organic acids in Arctic aerosols: speciation, annual variation and concentration levels, Atmos. Chem. Phys., 14, 7807-7823, doi:10.5194/acp-14-7807-2014, 2014.

Hatakeyama, S., Tanonaka, T., Weng, J. H., Bandow, H., Takagi, H., and Akimoto, H.: Ozone Cyclohexene Reaction in Air - Quantitative-Analysis of Particulate Products and the Reaction-Mechanism, Environ. Sci. Technol., 19, 935-942, doi:10.1021/Es00140a008, 1985.

Hawkins, L. N., Russell, L. M., Covert, D. S., Quinn, P. K., and Bates, T. S.: Carboxylic acids, sulfates, and organosulfates in processed continental organic aerosol over the southeast Pacific Ocean during VOCALS-REx 2008, J. Geophys. Res.-Atmos., 115, D13201, doi:10.1029/2009jd013276, 2010.

Heald, C. L., Kroll, J. H., Jimenez, J. L., Docherty, K. S., DeCarlo, P. F., Aiken, A. C., Chen, Q., Martin, S. T., Farmer, D. K., and Artaxo, P.: A simplified description of the evolution of organic aerosol composition in the atmosphere, Geophys. Res. Lett., 37, L08803, doi:10.1029/2010g1042737, 2010.

Hoffmann, T., Odum, J. R., Bowman, F., Collins, D., Klockow, D., Flagan, R. C., and Seinfeld, J. H.: Formation of organic aerosols from the oxidation of biogenic hydrocarbons, J. Atmos. Chem., 26, 189-222, 1997.

Hoyle, C. R., Boy, M., Donahue, N. M., Fry, J. L., Glasius, M., Guenther, A., Hallar, A. G., Huff Hartz, K., Petters, M. D., Petäjä, T., Rosenoern, T., and Sullivan, A. P.: A review of the anthropogenic influence on biogenic secondary organic aerosol, Atmos. Chem. Phys., 11, 321-343, doi:10.5194/acp-11-321-2011, 2011.

Iinuma, Y., Muller, C., Berndt, T., Boge, O., Claeys, M., and Herrmann, H.: Evidence for the existence of organosulfates from beta-pinene ozonolysis in ambient secondary organic aerosol, Environ. Sci. Technol., 41, 6678-6683, doi:10.1021/Es070938t, 2007a.

Iinuma, Y., Muller, C., Boge, O., Gnauk, T., and Herrmann, H.: The formation of organic sulfate esters in the limonene ozonolysis secondary organic aerosol (SOA) under acidic conditions, Atmos. Environ., 41, 5571-5583, doi:10.1016/j.atmosenv.2007.03.007, 2007b.

Iinuma, Y., Boge, O., Kahnt, A., and Herrmann, H.: Laboratory chamber studies on the formation of organosulfates from reactive uptake of monoterpene oxides, Phys. Chem. Chem. Phys., 11, 7985-7997, doi:10.1039/B904025k, 2009.

IPCC: Summary for Policymakers. In: Climate Change 2007: The Physical Science Basis. Contribution of Working Group I to the Fourth Assessment Report of the Intergovernmental Panel on Climate Change, edited by: Solomon, S., Qin, D., Manning, M., Chen, Z., Marquis, M., Averyt, K. B., Tignor, M., and Miller, H. L., Cambridge University Press, Cambridge, UK and New York, NY, USA, 2007.
Jaoui, M., Corse, E. W., Lewandowski, M., Offenberg, J. H., Kleindienst, T. E., and Edney, E. O.: Formation of organic tracers for isoprene SOA under acidic conditions, Atmos. Environ., 44, 1798-1805, doi:10.1016/j.atmosenv.2010.01.018, 2010.

Jimenez, J. L., Canagaratna, M. R., Donahue, N. M., Prevot, A. S. H., Zhang, Q., Kroll, J. H., DeCarlo, P. F., Allan, J. D., Coe, H., Ng, N. L., Aiken, A. C., Docherty, K. S., Ulbrich, I. M., Grieshop, A. P., Robinson, A. L., Duplissy, J., Smith, J. D., Wilson, K. R., Lanz, V. A., Hueglin, C., Sun, Y. L., Tian, J., Laaksonen, A., Raatikainen, T., Rautiainen, J., Vaattovaara, P., Ehn, M., Kulmala, M., Tomlinson, J. M., Collins, D. R., Cubison, M. J., Dunlea, E. J., Huffman, J. A., Onasch, T. B., Alfarra, M. R., Williams, P. I., Bower, K., Kondo, Y., Schneider, J., Drewnick, F., Borrmann, S., Weimer, S., Demerjian, K., Salcedo, D., Cottrell, L., Griffin, R., Takami, A., Miyoshi, T., Hatakeyama, S., Shimono, A., Sun, J. Y., Zhang, Y. M., Dzepina, K., Kimmel, J. R., Sueper, D., Jayne, J. T., Herndon, S. C., Trimborn, A. M., Williams, L. R., Wood, E. C., Middlebrook, A. M., Kolb, C. E., Baltensperger, U., and Worsnop, D. R.: Evolution of Organic Aerosols in the Atmosphere, Science, 326, 1525-1529, doi:10.1126/science.1180353, 2009.

Jokinen, V. and Makela, J. M.: Closed-loop arrangement with critical orifice for DMA sheath excess flow system, J. Aerosol Sci., 28, 643-648, 1997.

Kleindienst, T. E., Jaoui, M., Lewandowski, M., Offenberg, J. H., and Docherty, K. S.: The formation of SOA and chemical tracer compounds from the photooxidation of naphthalene and its methyl analogs in the presence and absence of nitrogen oxides, Atmos. Chem. Phys., 12, 8711-8726, doi:10.5194/acp-12-87112012, 2012.

Koch, S., Winterhalter, R., Uherek, E., Kolloff, A., Neeb, P., and Moortgat, G. K.: Formation of new particles in the gas-phase ozonolysis of monoterpenes, Atmos. Environ., 34, 4031-4042, doi:10.1016/S1352-2310(00)00133-3, 2000.

Kristensen, K. and Glasius, M.: Organosulfates and oxidation products from biogenic hydrocarbons in fine aerosols from a forest in North West Europe during spring, Atmos. Environ., 45, 45464556, doi:10.1016/j.atmosenv.2011.05.063, 2011.

Kroll, J. H. and Seinfeld, J. H.: Chemistry of secondary organic aerosol: Formation and evolution of low-volatility organics in the atmosphere, Atmos. Environ., 42, 3593-3624, doi:10.1016/j.atmosenv.2008.01.003, 2008.

Kulmala, M., Laakso, L., Lehtinen, K. E. J., Riipinen, I., Dal Maso, M., Anttila, T., Kerminen, V.-M., Hõrrak, U., Vana, M., and Tammet, H.: Initial steps of aerosol growth, Atmos. Chem. Phys., 4, 2553-2560, doi:10.5194/acp-4-2553-2004, 2004a.

Kulmala, M., Vehkamaki, H., Petaja, T., Dal Maso, M., Lauri, A., Kerminen, V. M., Birmili, W., and McMurry, P. H.: Formation and growth rates of ultrafine atmospheric particles: a review of observations, J. Aerosol Sci., 35, 143-176, doi:10.1016/j.jaerosci.2003.10.003, 2004b.

Larsen, B. R., Di Bella, D., Glasius, M., Winterhalter, R., Jensen, N. R., and Hjorth, J.: Gas-phase OH oxidation of monoterpenes: Gaseous and particulate products, J. Atmos. Chem., 38, 231-276, doi:10.1023/A:1006487530903, 2001.

Librando, V. and Tringali, G.: Atmospheric fate of $\mathrm{OH}$ initiated oxidation of terpenes. Reaction mechanism of alpha-pinene degradation and secondary organic aerosol formation, J. Envi- 
ron. Manage., 75, 275-282, doi:10.1016/j.jenvman.2005.01.001, 2005.

Lin, Y. H., Zhang, Z. F., Docherty, K. S., Zhang, H. F., Budisulistiorini, S. H., Rubitschun, C. L., Shaw, S. L., Knipping, E. M., Edgerton, E. S., Kleindienst, T. E., Gold, A., and Surratt, J. D.: Isoprene Epoxydiols as Precursors to Secondary Organic Aerosol Formation: Acid-Catalyzed Reactive Uptake Studies with Authentic Compounds, Environ. Sci. Technol., 46, 250258, doi:10.1021/Es202554c, 2012.

Lin, Y. H., Zhang, H. F., Pye, H. O. T., Zhang, Z. F., Marth, W. J., Park, S., Arashiro, M., Cui, T. Q., Budisulistiorini, H., Sexton, K. G., Vizuete, W., Xie, Y., Luecken, D. J., Piletic, I. R., Edney, E. O., Bartolotti, L. J., Gold, A., and Surratt, J. D.: Epoxide as a precursor to secondary organic aerosol formation from isoprene photooxidation in the presence of nitrogen oxides, P. Natl. Acad. Sci. USA, 110, 6718-6723, doi:10.1073/pnas.1221150110, 2013.

Ljungstrom, E. and Hallquist, M.: Nitrate radical formation rates in Scandinavia, Atmos. Environ., 30, 2925-2932, doi:10.1016/1352-2310(96)00006-4, 1996.

Lyubovtseva, Y. S., Sogacheva, L., Dal Maso, M., Bonn, B., Keronen, P., and Kulmala, M.: Seasonal variations of trace gases, meteorological parameters, and formation of aerosols in boreal forests, Boreal Environ. Res., 10, 493-510, 2005.

Ma, Y., Willcox, T. R., Russell, A. T., and Marston, G.: Pinic and pinonic acid formation in the reaction of ozone with alphapinene, Chem. Commun., 1328-1330, 2007.

Minerath, E. C. and Elrod, M. J.: Assessing the Potential for Diol and Hydroxy Sulfate Ester Formation from the Reaction of Epoxides in Tropospheric Aerosols, Environ. Sci. Technol., 43, 13861392, doi:10.1021/Es8029076, 2009.

Mochida, M., Kawabata, A., Kawamura, K., Hatsushika, H., and Yamazaki, K.: Seasonal variation and origins of dicarboxylic acids in the marine atmosphere over the western North Pacific, J. Geophys. Res.-Atmos., 108, 4193, doi:10.1029/2002jd002355, 2003

Müller, L., Reinnig, M.-C., Naumann, K. H., Saathoff, H., Mentel, T. F., Donahue, N. M., and Hoffmann, T.: Formation of 3-methyl1,2,3-butanetricarboxylic acid via gas phase oxidation of pinonic acid - a mass spectrometric study of SOA aging, Atmos. Chem. Phys., 12, 1483-1496, doi:10.5194/acp-12-1483-2012, 2012.

Nozière, B., Ekström, S., Alsberg, T., and Holmström, S.: Radical-initiated formation of organosulfates and surfactants in atmospheric aerosols, Geophys. Res. Lett., 37, L05806, doi:10.1029/2009GL041683, 2010.

Olson, C. N., Galloway, M. M., Yu, G., Hedman, C. J., Lockett, M. R., Yoon, T., Stone, E. A., Smith, L. M., and Keutsch, F. N.: Hydroxycarboxylic Acid-Derived Organosulfates: Synthesis, Stability, and Quantification in Ambient Aerosol, Environ. Sci. Technol., 45, 6468-6474, doi:10.1021/Es201039p, 2011.

Reemtsma, T., These, A., Venkatachari, P., Xia, X., Hopke, P. K., Springer, A., and Linscheid, M.: Identification of Fulvic Acids and Sulfated and Nitrated Analogues in Atmospheric Aerosol by Electrospray Ionization Fourier Transform Ion Cyclotron Resonance Mass Spectrometry, Anal. Chem., 78, 8299-8304, doi:10.1021/ac061320p, 2006.

Rogge, W. F., Hildemann, L. M., Mazurek, M. A., Cass, G. R., and Simonelt, B. R. T.: Sources of Fine Organic Aerosol .1. Char- broilers and Meat Cooking Operations, Environ. Sci. Technol., 25, 1112-1125, doi:10.1021/Es00018a015, 1991.

Rogge, W. F., Hildemann, L. M., Mazurek, M. A., Cass, G. R., and Simoneit, B. R. T.: Sources of fine organic aerosol. 9. Pine, oak and synthetic log combustion in residential fireplaces, Environ. Sci. Technol., 32, 13-22, doi:10.1021/Es960930b, 1998.

Rollins, A. W., Pusede, S., Wooldridge, P., Min, K. E., Gentner, D. R., Goldstein, A. H., Liu, S., Day, D. A., Russell, L. M., Rubitschun, C. L., Surratt, J. D., and Cohen, R. C.: Gas/particle partitioning of total alkyl nitrates observed with TDLIF in Bakersfield, J. Geophys. Res.-Atmos., 118, 6651-6662, doi:10.1002/Jgrd.50522, 2013.

Schauer, J. J., Fraser, M. P., Cass, G. R., and Simoneit, B. R. T.: Source reconciliation of atmospheric gas-phase and particlephase pollutants during a severe photochemical smog episode, Environ. Sci. Technol., 36, 3806-3814, doi:10.1021/Es011458j, 2002.

Spracklen, D. V., Jimenez, J. L., Carslaw, K. S., Worsnop, D. R., Evans, M. J., Mann, G. W., Zhang, Q., Canagaratna, M. R., Allan, J., Coe, H., McFiggans, G., Rap, A., and Forster, P.: Aerosol mass spectrometer constraint on the global secondary organic aerosol budget, Atmos. Chem. Phys., 11, 12109-12136, doi:10.5194/acp-11-12109-2011, 2011.

Stock, M., Cheng, Y. F., Birmili, W., Massling, A., Wehner, B., Müller, T., Leinert, S., Kalivitis, N., Mihalopoulos, N., and Wiedensohler, A.: Hygroscopic properties of atmospheric aerosol particles over the Eastern Mediterranean: implications for regional direct radiative forcing under clean and polluted conditions, Atmos. Chem. Phys., 11, 4251-4271, doi:10.5194/acp11-4251-2011, 2011.

Suh, I., Zhang, R. Y., Molina, L. T., and Molina, M. J.: Oxidation mechanism of aromatic peroxy and bicyclic radicals from OH-toluene reactions, J. Am. Chem. Soc., 125, 12655-12665, doi:10.1021/Ja0350280, 2003.

Surratt, J. D., Murphy, S. M., Kroll, J. H., Ng, N. L., Hildebrandt, L., Sorooshian, A., Szmigielski, R., Vermeylen, R., Maenhaut, W., Claeys, M., Flagan, R. C., and Seinfeld, J. H.: Chemical composition of secondary organic aerosol formed from the photooxidation of isoprene, J. Phys. Chem. A, 110, 9665-9690, doi:10.1021/Jp061734m, 2006.

Surratt, J. D., Kroll, J. H., Kleindienst, T. E., Edney, E. O., Claeys, M., Sorooshian, A., Ng, N. L., Offenberg, J. H., Lewandowski, M., Jaoui, M., Flagan, R. C., and Seinfeld, J. H.: Evidence for organosulfates in secondary organic aerosol, Environ. Sci. Technol., 41, 517-527, 2007a.

Surratt, J. D., Lewandowski, M., Offenberg, J. H., Jaoui, M., Kleindienst, T. E., Edney, E. O., and Seinfeld, J. H.: Effect of acidity on secondary organic aerosol formation from isoprene, Environ. Sci. Technol., 41, 5363-5369, 2007b.

Surratt, J. D., Lewandowski, M., Offenberg, J. H., Jaoui, M., Kleindienst, T. E., Edney, E. O., and Seinfeld, J. H.: Effect of acidity on secondary organic aerosol formation from isoprene, Environ. Sci. Technol., 41, 5363-5369, doi:10.1021/Es0704176, 2007c.

Surratt, J. D., Gomez-Gonzalez, Y., Chan, A. W., Vermeylen, R., Shahgholi, M., Kleindienst, T. E., Edney, E. O., Offenberg, J. H., Lewandowski, M., Jaoui, M., Maenhaut, W., Claeys, M., Flagan, R. C., and Seinfeld, J. H.: Organosulfate formation in biogenic secondary organic aerosol, J. Phys. Chem. A, 112, 8345-8378, 10.1021/jp802310p, 2008a. 
Surratt, J. D., Gomez-Gonzalez, Y., Chan, A. W. H., Vermeylen, R., Shahgholi, M., Kleindienst, T. E., Edney, E. O., Offenberg, J. H., Lewandowski, M., Jaoui, M., Maenhaut, W., Claeys, M., Flagan, R. C., and Seinfeld, J. H.: Organosulfate formation in biogenic secondary organic aerosol, J. Phys. Chem. A, 112, 8345-8378, doi:10.1021/Jp802310p, 2008b.

Surratt, J. D., Chan, A. W., Eddingsaas, N. C., Chan, M., Loza, C. L., Kwan, A. J., Hersey, S. P., Flagan, R. C., Wennberg, P. O., and Seinfeld, J. H.: Reactive intermediates revealed in secondary organic aerosol formation from isoprene, P. Natl. Acad. Sci. USA, 107, 6640-6645, doi:10.1073/pnas.0911114107, 2010.

Szidat, S., Jenk, T. M., Synal, H. A., Kalberer, M., Wacker, L., Hajdas, I., Kasper-Giebl, A., and Baltensperger, U.: Contributions of fossil fuel, biomass-burning, and biogenic emissions to carbonaceous aerosols in Zurich as traced by C-14, J. Geophys. Res.Atmos., 111, D07206, doi:10.1029/2005jd006590, 2006.

Szidat, S., Ruff, M., Perron, N., Wacker, L., Synal, H.-A., Hallquist, M., Shannigrahi, A. S., Yttri, K. E., Dye, C., and Simpson, D.: Fossil and non-fossil sources of organic carbon (OC) and elemental carbon (EC) in Göteborg, Sweden, Atmos. Chem. Phys., 9, 1521-1535, doi:10.5194/acp-9-1521-2009, 2009.

Szmigielski, R., Surratt, J. D., Gomez-Gonzalez, Y., Van der Veken, P., Kourtchev, I., Vermeylen, R., Blockhuys, F., Jaoui, M., Kleindienst, T. E., Lewandowski, M., Offenberg, J. H., Edney, E. O., Seinfeld, J. H., Maenhaut, W., and Claeys, M.: 3-methyl1,2,3-butanetricarboxylic acid: An atmospheric tracer for terpene secondary organic aerosol, Geophys. Res. Lett., 34, L24811, doi:10.1029/2007g1031338, 2007.

Tolocka, M. P. and Turpin, B.: Contribution of Organosulfur Compounds to Organic Aerosol Mass, Environ. Sci. Technol., 46, 7978-7983, doi:10.1021/Es300651v, 2012.

Wiedensohler, A.: An Approximation of the Bipolar ChargeDistribution for Particles in the Sub-Micron Size Range, J. Aerosol Sci., 19, 387-389, 1988.

Wilks, D. S.: Statistical methods in the atmospheric sciences, 3rd Edn., International geophysics series, 100, Elsevier/Academic Press, Amsterdam, Boston, 676 pp., 2011.

Winklmayer, W., Reischl, G. P., Lindner, A. O., and Berner, A.: New electromobility spectrometer for the measurement of aerosol size distributions in the size range 1 to $1000 \mathrm{~nm}$, J. Aerosol Sci., 22, 289-296, 1991.

Worton, D. R., Goldstein, A. H., Farmer, D. K., Docherty, K. S., Jimenez, J. L., Gilman, J. B., Kuster, W. C., de Gouw, J., Williams, B. J., Kreisberg, N. M., Hering, S. V., Bench, G., McKay, M., Kristensen, K., Glasius, M., Surratt, J. D., and Seinfeld, J. H.: Origins and composition of fine atmospheric carbonaceous aerosol in the Sierra Nevada Mountains, California, Atmos. Chem. Phys., 11, 10219-10241, doi:10.5194/acp-1110219-2011, 2011

Worton, D. R., Surratt, J. D., LaFranchi, B. W., Chan, A. W. H., Zhao, Y. L., Weber, R. J., Park, J. H., Gilman, J. B., de Gouw, J., Park, C., Schade, G., Beaver, M., St Clair, J. M., Crounse, J., Wennberg, P., Wolfe, G. M., Harrold, S., Thornton, J. A., Farmer, D. K., Docherty, K. S., Cubison, M. J., Jimenez, J. L., Frossard, A. A., Russell, L. M., Kristensen, K., Glasius, M., Mao, J. Q., Ren, X. R., Brune, W., Browne, E. C., Pusede, S. E., Cohen, R. C., Seinfeld, J. H., and Goldsteint, A. H.: Observational Insights into Aerosol Formation from Isoprene, Environ. Sci. Technol., 47, 11403-11413, doi:10.1021/Es4011064, 2013.
Yasmeen, F., Vermeylen, R., Maurin, N., Perraudin, E., Doussin, J. F., and Claeys, M.: Characterisation of tracers for aging of alpha-pinene secondary organic aerosol using liquid chromatography/negative ion electrospray ionisation mass spectrometry, Environ. Chem., 9, 236-246, doi:10.1071/En11148, 2012.

Yu, J. Z., Cocker, D. R., Griffin, R. J., Flagan, R. C., and Seinfeld, J. H.: Gas-phase ozone oxidation of monoterpenes: Gaseous and particulate products, J. Atmos. Chem., 34, 207-258, doi:10.1023/A:1006254930583, 1999.

Zare, A., Christensen, J. H., Irannejad, P., and Brandt, J.: Evaluation of two isoprene emission models for use in a longrange air pollution model, Atmos. Chem. Phys., 12, 7399-7412, doi:10.5194/acp-12-7399-2012, 2012.

Zare, A., Christensen, J. H., Gross, A., Irannejad, P., Glasius, M., and Brandt, J.: Quantifying the contributions of natural emissions to ozone and total fine PM concentrations in the Northern Hemisphere, Atmos. Chem. Phys., 14, 2735-2756, doi:10.5194/acp14-2735-2014, 2014.

Zhang, H., Zhang, Z., Cui, T., Lin, Y.-H., Bhathela, N. A., Ortega, J., Worton, D. R., Goldstein, A. H., Guenther, A., Jimenez, J. L., Gold, A., and Surratt, J. D.: Secondary Organic Aerosol Formation via 2-Methyl-3-buten-2-ol Photooxidation: Evidence of Acid-Catalyzed Reactive Uptake of Epoxides, Environ. Sci. Technol. Lett., 1, 242-247, doi:10.1021/ez500055f, 2014.

Zhang, H. F., Lin, Y. H., Zhang, Z. F., Zhang, X. L., Shaw, S. L., Knipping, E. M., Weber, R. J., Gold, A., Kamens, R. M., and Surratt, J. D.: Secondary organic aerosol formation from methacrolein photooxidation: roles of $\mathrm{NO}_{\mathrm{x}}$ level, relative humidity and aerosol acidity, Environ. Chem., 9, 247-262, doi:10.1071/En12004, 2012a.

Zhang, H. F., Worton, D. R., Lewandowski, M., Ortega, J., Rubitschun, C. L., Park, J. H., Kristensen, K., Campuzano-Jost, P., Day, D. A., Jimenez, J. L., Jaoui, M., Offenberg, J. H., Kleindienst, T. E., Gilman, J., Kuster, W. C., de Gouw, J., Park, C., Schade, G. W., Frossard, A. A., Russell, L., Kaser, L., Jud, W., Hansel, A., Capellin, L., Karl, T., Glasius, M., Guenther, A., Goldstein, A. H., Seinfeld, J. H., Gold, A., Kamens, R. M., and Surratt, J. D.: Organosulfates as Tracers for Secondary Organic Aerosol (SOA) Formation from 2-Methyl-3-Buten-2-ol (MBO) in the Atmosphere, Environ. Sci. Technol., 46, 94379446, doi:10.1021/Es301648z, 2012b.

Zhang, H. F., Worton, D. R., Lewandowski, M., Ortega, J., Rubitschun, C. L., Park, J. H., Kristensen, K., Campuzano-Jost, P., Day, D. A., Jimenez, J. L., Jaoui, M., Offenberg, J. H., Kleindienst, T. E., Gilman, J., Kuster, W. C., de Gouw, J., Park, C., Schade, G. W., Frossard, A. A., Russell, L., Kaser, L., Jud, W., Hansel, A., Cappellin, L., Karl, T., Glasius, M., Guenther, A., Goldstein, A. H., Seinfeld, J. H., Gold, A., Kamens, R. M., and Surratt, J. D.: Organosulfates as Tracers for Secondary Organic Aerosol (SOA) Formation from 2-Methyl-3-Buten-2-ol (MBO) in the Atmosphere, Environ. Sci. Technol., 46, $9437-$ 9446, doi:10.1021/Es301648z, 2012c. 